\title{
The effect of substituents on the syn-anti conformer ratio in naphthyl-based imidazolinium salts and their corresponding $N$-heterocyclic carbenes
}

\author{
Michele Gatti, Linglin Wu, Emma Drinkel, Fiona Gaggia, Sascha Blumentritt, Anthony \\ Linden, and Reto Dorta* \\ Organic Chemistry Institute, University of Zurich, Winterthurerstrasse 190, \\ CH-8057, Zurich, Switzerland \\ E-mail:dorta@oci.uzh.ch
}

Dedicated to Prof. Dr. Heinz Heimgartner, a true gentleman, on the occasion of his $70^{\text {th }}$ birthday

\begin{abstract}
Eight new N-heterocyclic carbenes (NHCs) featuring substituted naphthyl side chains were synthesized. These molecules are present in solution as a stable mixture of anti and syn conformers. Through careful tuning of the substituents on position 2 and 2,7 of the naphthyl moieties, it was possible to synthesize molecules that display a strong preference for the anti conformation (up to 95:5). This will greatly facilitate their optimized use as single isomeric ligands in metal-catalysis and as organocatalysts.
\end{abstract}

Keywords: N-Heterocyclic carbenes, naphthyl substituents, iron coupling, syn-anti isomers

\section{Introduction}

The affirmation of N-heterocyclic carbenes as ligands for transition metals catalysts and as organic catalysts proved to be an important innovation in the field of catalysis. ${ }^{1,2}$ Especially useful in this respect (so far) have been $\mathrm{N}$-heterocyclic carbenes with five-membered heterocyclic structures first reported by Arduengo et al., such as imidazol-2-ylidene $\mathbf{A}$ and the saturated heterocyclic imidazolidin-2-ylidene derivatives $\mathbf{B}^{3,4}$

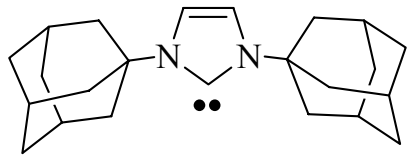

A

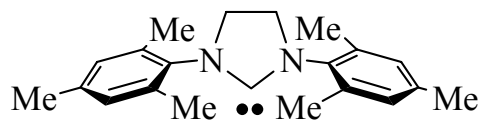

B 
Whereas dozens of structural variations of NHCs A and B exist nowadays, the overwhelming majority incorporate the unsaturated central N-heterocycle of $\mathbf{A}$. The reason for this lies in the surprisingly different stabilities of unsaturated and saturated NHCs. While dimerization of aromatically stabilized N-heterocyclic carbenes of type $\mathbf{A}$ is thermodynamically unfavorable even for small $\mathrm{N}$-substituents like $\mathrm{R}=\mathrm{Me},{ }^{5,6}$ formation of the enetetramine dimer of $\mathbf{B}$ occurs readily. This renders saturated NHCs considerably less amenable to catalysis and restricts access to stable modifications of this ligand class, as the substituents at the nitrogen atoms need to be very bulky in order to prevent dimerization. The demarcation line separating stable from unstable carbenes may be established and lies somewhere between ${ }^{t} \mathrm{Bu} /{ }^{i} \mathrm{Pr}$ for $\mathrm{N}$-alkyl substituents and $\mathrm{Mes} / \mathrm{Ph}$ for aromatic side chains. ${ }^{7-9}$

In catalysis, work in the last decade has shown that monodentate NHCs with bulky, arylsubstituted side chains are the overall most successful design. As such, 2,4,6-mesityl-substituted IMes and 2,6-isopropylphenyl-substituted $\operatorname{IPr}$ and their saturated imidazolin-2-ylidene counterparts (SIMes and SIPr) still remain the only ligands that represent a truly viable alternative to phosphines, in terms of both versatility and reactivity.

Our entry in this fascinating field of research began with the design and the synthesis of stable saturated free carbenes that feature substituted naphthyl side chains. ${ }^{10} \mathrm{We}$ reasoned that this architecture would mimic well the original SIMes and SIPr ligand systems, offering at the same time a scaffold that is less hindered in proximity to the potential metal binding site and that can be functionalized more readily with a wide range of substituents, tuning both its steric and electronic properties (Figure 1).



SIMes

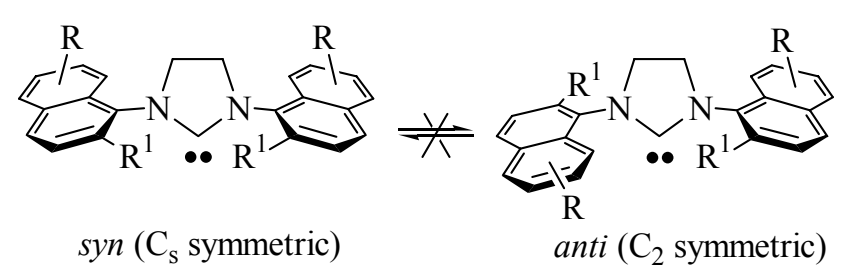

Figure 1. Imidazolin-2-ylidenes with phenyl (left) and naphthyl (right) side chains.

The substitution pattern confers to these molecules a high degree of conformational stability, generating in solution a mixture of anti and syn conformers (Figure 1). A detailed NMR study on the fluxional behavior of this class of carbenes showed that, even at high temperature, interconversion between the conformers is not possible if sterically demanding substituents are present in position 2 of the naphthyl side chains $\left(\mathrm{R}^{1}\right.$ in Figure 1). ${ }^{11}$ This encouraged us to attempt the separation of the syn and anti isomers for some of these molecules but this process, up to now, has been successful only when the NHC was incorporated into a stable metal complex. Recent studies performed in our laboratory also indicated that, for some types of metal-catalyzed transformations, organometallic catalysts containing NHCs in the anti isomeric form perform better than the ones in the syn form. ${ }^{12}$ 
These reasons prompted us to attempt the synthesis of molecules displaying a conformational preference for only one of the two isomers. Herein, we describe the synthesis of a series of new saturated NHCs that incorporate alkylated naphthyl side chains. With the aim of minimizing the formation of the syn isomer, we selected a bulky, linear alkyl substituent, as well as relatively rigid, cyclic alkyl derivatives of various sizes for incorporation at positions 2 and 2,7 of the naphthalene units.

\section{Results and Discussion}

Synthesis of free NHCs began with the preparation of mono- and dialkylated naphthalene rings. Compounds 1a-d were obtained starting from 2-bromonaphthalene and the desired alkyl bromide via an iron-catalyzed $\mathrm{C}_{\mathrm{sp} 2}-\mathrm{C}_{\mathrm{sp} 3}$ coupling adapting a procedure reported recently by Cahiez et al. (Scheme 1). ${ }^{13}$ After initial formation of the mono-Grignard derivative of naphthalene, the solution/suspension was added to the respective alkylbromide solution in THF containing the $\left(\mathrm{FeCl}_{3}\right)_{2}(\mathrm{TMEDA})_{3}$ catalyst $(4.6 \mathrm{~mol} \% \mathrm{Fe})$. After appropriate aqueous workup, elimination of naphthalene, the main byproduct of the reaction, was easily achieved via sublimation under high vacuum. The reaction proceeded in all cases with good yields, apparently unaffected by the increasing bulkiness of the alkyl halide employed (Scheme 1).

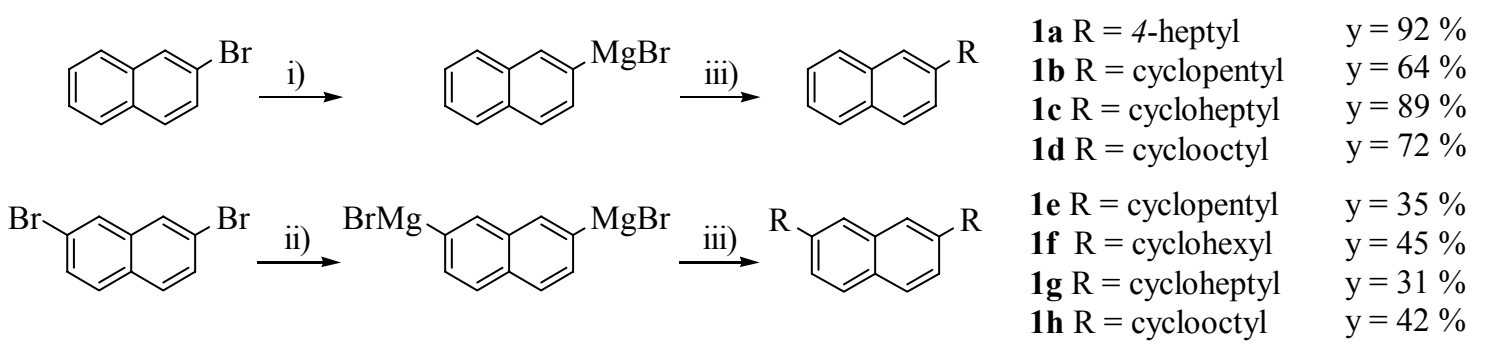

Reaction conditions: i) $\mathrm{Mg}$, THF, $\mathrm{I}_{2}$ (cat.), $60^{\circ} \mathrm{C}$. ii) $\mathrm{Mg}$, THF, $\mathrm{I}_{2}$ (cat.), reflux. iii) $\left(\mathrm{FeCl}_{3}\right)_{2}(\mathrm{TMEDA})_{3}$ (cat.), THF, RBr

Scheme 1. General synthesis of new 2- and 2,7-substituted naphthalenes.

Compounds 1e-h were obtained in a similar manner, starting from 2,7-dibromonaphthalene. ${ }^{14}$ Generation of the di-Grignard reagent, required for the subsequent coupling reaction, proceeded without problems when heating a THF solution at reflux temperature for several hours. The resulting di-Grignard compound can be used directly as a heavy suspension in THF or it can be isolated under nitrogen as a white stable powder after evaporation of the solvent. The diGrignard is then slowly added (as powder or as suspension) to the mixture of catalyst (7 mol\% $\mathrm{Fe}$ ) and alkyl bromide, resulting in a rapid color change of the reaction to dark brown/black and this color was maintained upon completion of the reaction. After standard aqueous work up and passing the solution through a short silicagel plug, ${ }^{15}$ the final purification of the product was performed via bulb-to-bulb high vacuum distillation (Kugelrohr) to separate the desired product 
from the monoalkylated naphthalene compound (the main secondary product of the reaction) and from naphthalene. This purification method allowed an easy scaling up of the reaction to (at least) 10 grams. The isolated yields were generally not very high (35 to $45 \%$ ), but the reaction procedure proved to be robust and suitable for a wide range of commercially available bromoalkanes. Indeed, and to the best of our knowledge, these are the first examples reported in the literature of an iron-catalyzed double Kumada-type $\mathrm{C}_{\mathrm{sp} 2}-\mathrm{C}_{\mathrm{sp} 3}$ coupling.

Bromination of the alkylnaphthalenes (Scheme 2) was achieved in all cases with excellent yield and with perfect regioselectivity for position 1 of the naphthalene when performing the reaction at low temperature $\left(-78{ }^{\circ} \mathrm{C}\right)$ using equimolar amounts of $\mathrm{Br}_{2}$ with $\mathrm{CH}_{2} \mathrm{Cl}_{2}$ as the solvent. ${ }^{16}$ The control of the temperature is particularly important for 2-alkylnaphthalenes; when the reaction is performed at $0{ }^{\circ} \mathrm{C}$, a mixture of regioisomers is obtained whose separation by column chromatography is not trivial. ${ }^{17}$ Quenching of the reaction involved addition of a diluted aqueous solution of $\mathrm{NaOH}$ to the reaction solution at $-78{ }^{\circ} \mathrm{C}$, as the more commonly used $\mathrm{Na}_{2} \mathrm{~S}_{2} \mathrm{O}_{3}$ agent was found to sometimes interfere with the subsequent metal-catalyzed reaction step. This double Buchwald-Hartwig coupling with ethylenediamine in the presence of $\mathrm{Pd}(\mathrm{dba})_{2}$ (10 mol\%), ( \pm )-BINAP (11 mol\%) and $\mathrm{NaO}^{t} \mathrm{Bu}(3 \mathrm{eq})$ generated diamines 3a-h in good yield and high purity after chromatographic purification.
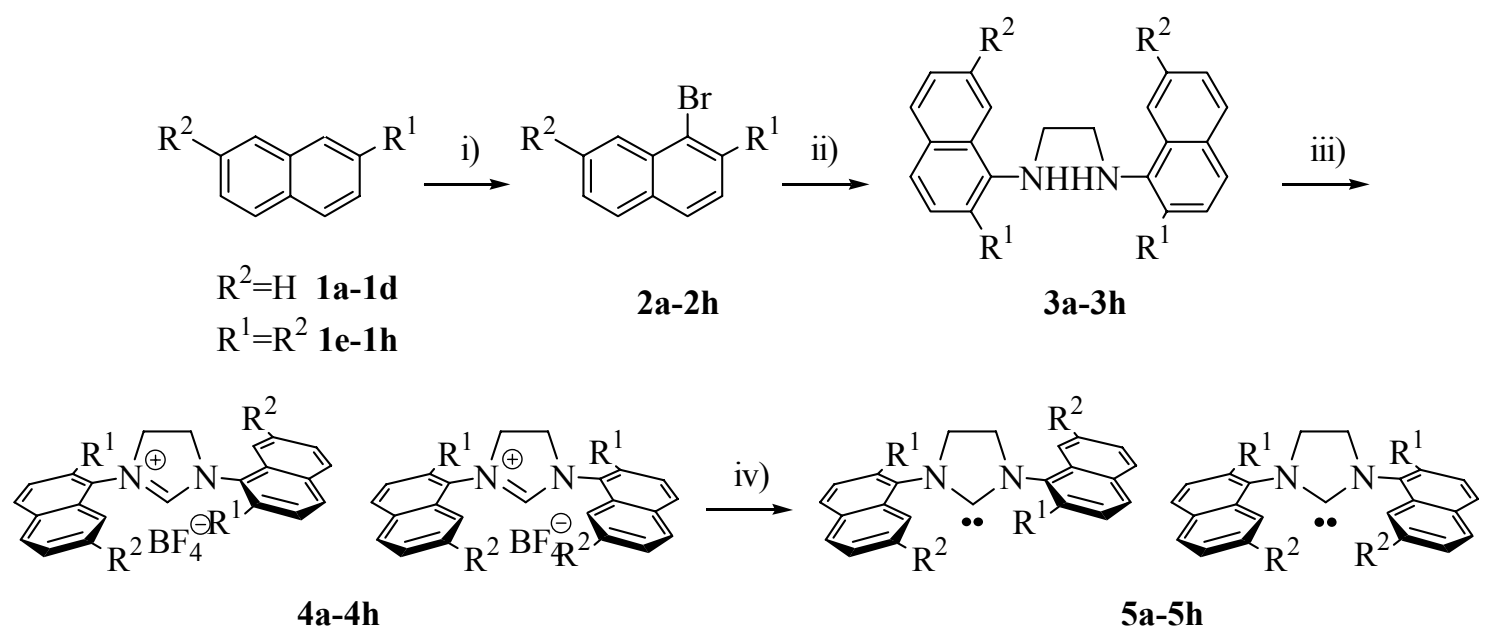

Reaction conditions: i) $\mathrm{Br}_{2}, \mathrm{CH}_{2} \mathrm{Cl}_{2},-78^{\circ} \mathrm{C}$; ii) ethylenediamine, $\mathrm{Pd}(\mathrm{dba})_{2}, \mathrm{rac}$ - $\mathrm{BINAP}, \mathrm{NaO}{ }^{\mathrm{t}} \mathrm{Bu}$, toluene, $110^{\circ} \mathrm{C}$;

iii) $\mathrm{NH}_{4} \mathrm{BF}_{4}, \mathrm{HCO}_{2} \mathrm{H}$ (cat.), $\mathrm{HC}(\mathrm{OEt})_{3}, 100^{\circ} \mathrm{C}$, iv) $\mathrm{NaH}, \mathrm{KO}^{\mathrm{t}} \mathrm{Bu}$ (cat.), THF.

Scheme 2. General synthesis of the free NHCs featuring naphthyl side chains.

Following the procedure originally reported by Grubbs et al, ${ }^{18}$ ring-closing of the respective diamines in the presence of triethyl orthoformate as reagent/solvent and $\mathrm{NH}_{4} \mathrm{BF}_{4}$ furnished the desired imidazolinium salts $\mathbf{4 a - h}$ in generally good yields. Table 1 reports the yields for the ring formation step and the ratio of conformers (syn respectively anti) observed. To have a more 
general overview, data concerning naphthyl-based NHC salts already reported by our group are also shown. ${ }^{10}$

Tendentially, yields are slightly lower when starting with diamines that contain very bulky substituents in position 2 of the naphthalene moiety (Table 1, entries 1-7) and with 2,7dialkylated precursors (Table 1, entires 8-13), probably reflecting an increasingly difficult approach of the nucleophile in the reaction sequence.

Concerning the syn/anti-ratio of the NHC salts, we note that when small non-cyclic alkyl groups are present in positions 2 or 2,7 of the naphthalene rings (entries 1-2 and 8-9 in Table 1), the two possible conformers were formed in almost equal amounts. Somewhat unexpected was the result for the 4-heptyl substituted derivative 4a, where we had hoped that the relatively important steric bulk would preferentially form the anti isomer, i.e. the isomer where the alkyl substituents would not sit on the same side with respect to each other (syn). Equal amounts of syn and anti isomers were also generated when a small, cyclic ring was present in position 2 or 2,7 (entry 4 and 10 in Table 1). Increasing progressively the bulkiness of the cyclic alkyl substituents (entries 5-7 in Table 1) favors the formation of the anti conformer. When large cyclic alkyl groups are present in both positions 2 and 7, the syn conformer becomes strongly disfavored and, in the best case (entry 11), a 95:5 anti-syn ratio is obtained.

Table 1. Yields and syn-anti ratio for compounds $\mathbf{4 a - 4 h}$ and previously reported imidazolinium salts containing naphthalene wingtips

\begin{tabular}{|c|c|c|c|}
\hline Entry & Imidazolinium salt & Yield (\%) & syn-anti ratio ${ }^{\mathrm{a}}$ \\
\hline 1 & (2)-SIMeNap'HBF ${ }_{4}{ }^{b}$ & 88 & $50: 50$ \\
\hline 2 & (2)-SIPrNap $\mathrm{HBF}_{4}{ }^{\mathrm{b}}$ & 60 & $50: 50$ \\
\hline 3 & (2)-SIHeptNap $\mathrm{HBF}_{4}(\mathbf{4 a})$ & 75 & $43: 57$ \\
\hline 4 & (2)-SICypentNap'HBF 4 (4b) & 75 & $50: 50$ \\
\hline 5 & (2)-SICyNap $\cdot \mathrm{HBF}_{4}{ }^{\mathrm{b}}$ & 78 & $27: 72$ \\
\hline 6 & (2)-SICyheptNap'HBF 4 (4c) & 58 & $22: 78$ \\
\hline 7 & (2)-SICyoctNap $\mathrm{HBF}_{4}(\mathbf{4 d})$ & 60 & $17: 83$ \\
\hline 8 & $(2,7)-\mathrm{SIMeNap} \mathrm{HBF}_{4}{ }^{\mathrm{b}}$ & 80 & $50: 50$ \\
\hline 9 & $(2,7)-\mathrm{SIPrNap} \cdot \mathrm{HBF}_{4}{ }^{\mathrm{b}}$ & 56 & $50: 50$ \\
\hline 10 & $(2,7)$-SICypentNap $\cdot \mathrm{HBF}_{4}(\mathbf{4 e})$ & 35 & $50: 50$ \\
\hline 11 & $(2,7)-\mathrm{SICyNap} \mathrm{HBF}_{4}(\mathbf{4 f})$ & 50 & $5: 95$ \\
\hline 12 & $(2,7)-$ SICyheptNap $\mathrm{HBF}_{4}(\mathbf{4 g})$ & 48 & $15: 85$ \\
\hline 13 & $(2,7)-\mathrm{SICyoctNap} \mathrm{HBF}_{4}(\mathbf{4 h})$ & 29 & $10: 90$ \\
\hline
\end{tabular}

${ }^{\mathrm{a}}$ The ratios were deduced from NMR analysis. ${ }^{\mathrm{b}}$ These compounds have been reported before (ref. $10)$. 
Finally, and not surprisingly given our precedent studies, the NHC salts 4a-h could be cleanly converted to free monomeric NHCs 5a-h (Scheme 2), via deprotonation of the imidazolinium proton in THF with $\mathrm{NaH}$ in the presence of a catalytic amount of potassium tertbutoxide. ${ }^{1} \mathrm{H}$ NMR spectroscopy at $300 \mathrm{~K}$ of carbenes 5a-h revealed two sets of signals corresponding, within error, to the ratio of anti/syn isomers found in the starting imidazolinium salts. This, in turn, means that a sufficiently high barrier to rotation between the conformers exists and that no interconversion occurs during and after the deprotonation step. The most indicative spectroscopic signal for the generation of free carbene species comes from ${ }^{13} \mathrm{C} N M R$ spectra of 5a-h, which show resonances between $\delta 245-247$ for the carbenic carbon. ${ }^{19}$
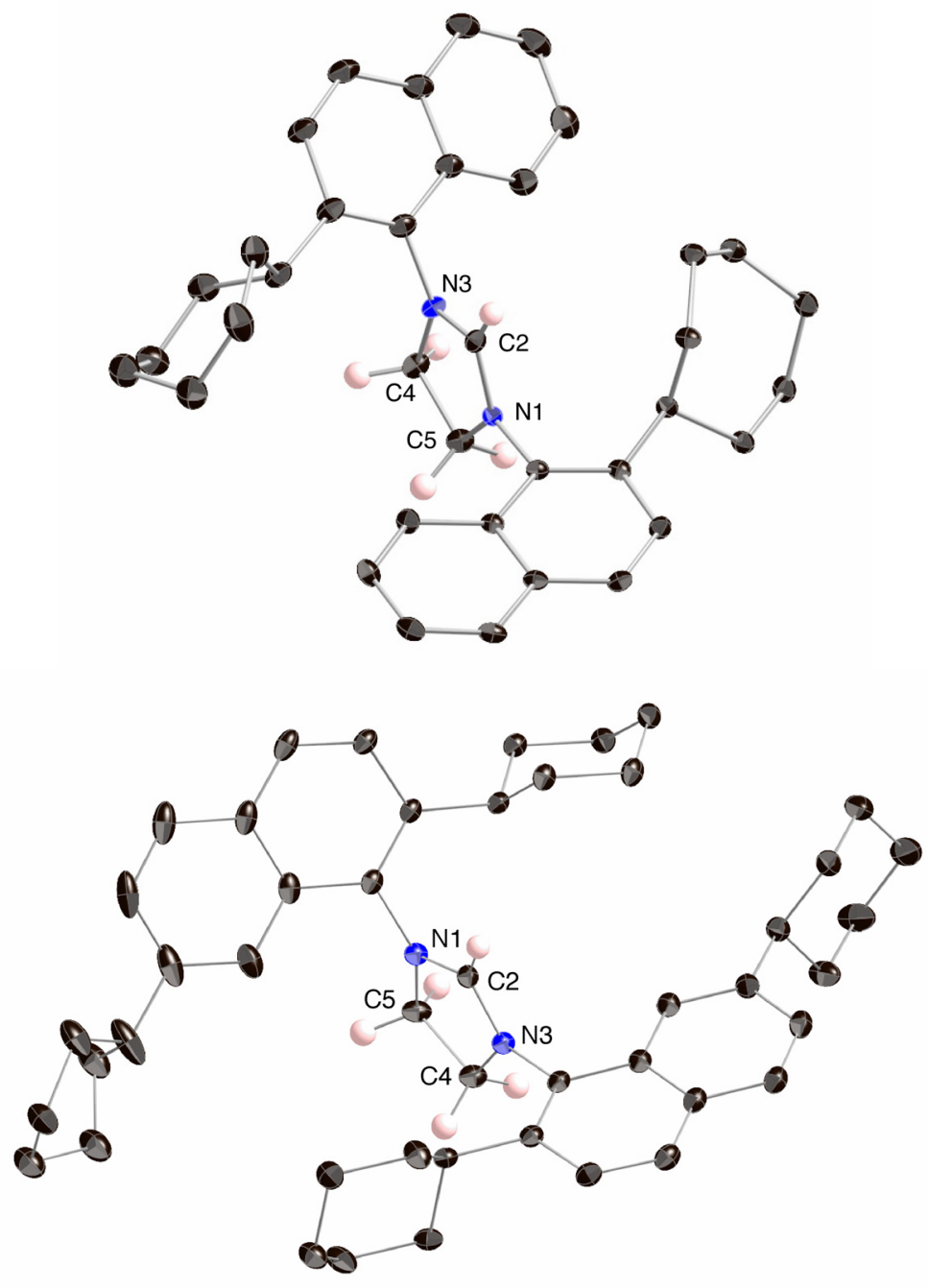


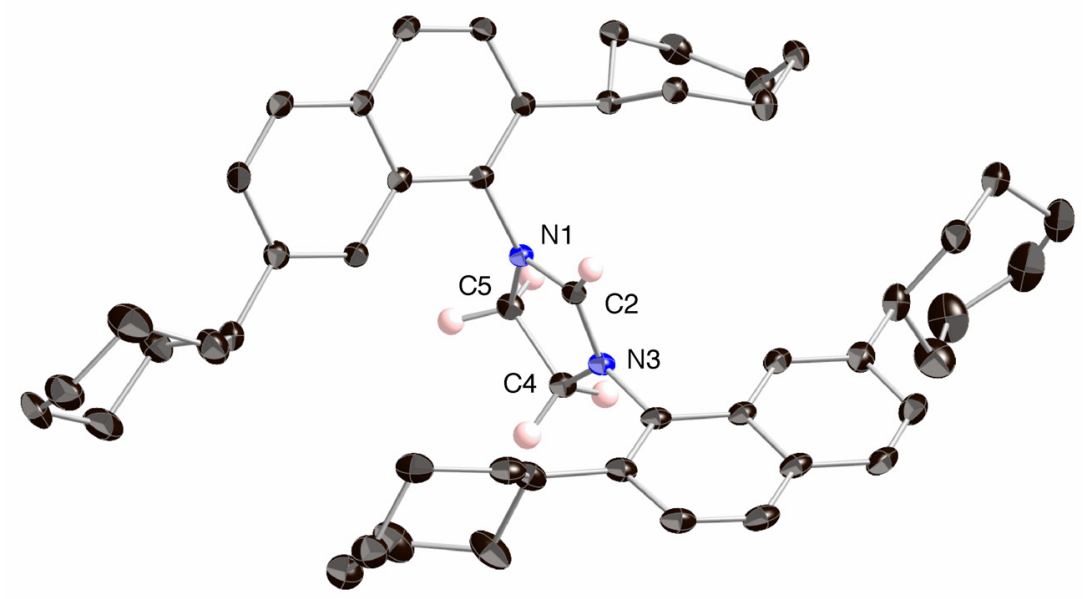

Figure 2. Displacement ellipsoid drawings (30\% probability) of the molecular structures of $\mathbf{4 c}$ (top), $\mathbf{4 f}$ (middle) and $\mathbf{4 g}$ (bottom). Hydrogen atoms (except for imidazolinium ring hydrogen atoms) and counterion $\left(\mathrm{BF}_{4}^{-}\right)$have been omitted for clarity.

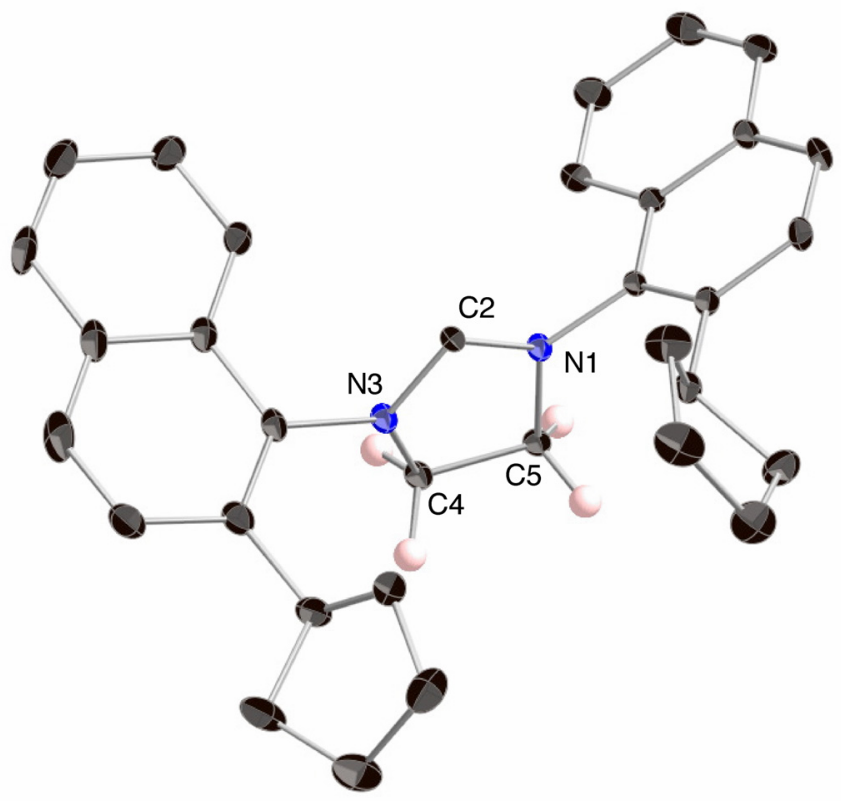

Figure 3. Displacement ellipsoid drawing (30\% probability) of the molecular structure of $\mathbf{5 b}$. Hydrogen atoms (except for imidazolinium ring hydrogen atoms) have been omitted for clarity.

All of the new imidazolinium salts 4a-h and free N-heterocyclic carbenes 5a-h were fully characterized, including single crystal X-ray diffraction studies of compounds $\mathbf{4 c}, \mathbf{4 f}$ and $\mathbf{4 g}$ and free carbene $\mathbf{5 b} .^{20}$ Displacement ellipsoid drawings of the salts are shown in Figure 2 and a representation of $\mathbf{5 b}$ can be found in Figure 3. Bond lengths and angles of the central fivemembered heterocycles of all known imidazolinium salts that incorporate naphthyl side chains are given in Tables 2 and 3. These tables also include the respective values for $\mathbf{5 b}$, our previously 
reported NHCs and the other two known structures in the literature, namely SIMes, ${ }^{4}$ and $\mathrm{SI}^{t} \mathrm{Bu}^{8 \mathrm{a}}$ The average length of the $\mathrm{C}_{2}-\mathrm{N}_{1(3)}$ bonds in these free carbenes increases only very slightly from the average values found in the imidazolinium salts and indicate a partial double bond character of these bonds. The remaining bond lengths in the five-membered N-heterocycle in both the salts and the free carbenes identify these as single bonds. The most apparent change in bond angles between imidazolinium salts and free carbenes can be found when looking at the $\mathrm{N}-\mathrm{C}-\mathrm{N}$ angles, which are about $9^{\circ}$ larger in the salts relative to those in the free carbene species. The opening of the $\mathrm{N}-\mathrm{C}-\mathrm{N}$ angle and the slight shortening of the $\mathrm{C}_{2}-\mathrm{N}_{1(3)}$ bonds in the salts may relieve some of the strain inherent in five-membered cycloalkane rings, which results in the familiar puckering of the ring into a half-chair or envelope conformation. Of the NHC salts in Table 2, all but one have quite planar five-membered heterocyclic rings, where the deviation of any atom from the mean plane through the ring is less than $0.03 \AA$. The exception is syn-(2,7)-SIPrNap $\mathrm{HCl}$ in which atoms $\mathrm{C}_{4}$ and $\mathrm{C}_{5}$ lie about $0.08 \AA$ from the mean plane, resulting in the ring having a shallow half-chair conformation twisted on $\mathrm{C}_{4}-\mathrm{C}_{5}$. Two of the free carbenes listed in Table 2, syn-(2,7)SIMeNap and anti-(2,7)-SIPrNap, have planar five-membered rings, while the corresponding rings in syn-(2)-SIPrNap and $\mathbf{5 b}$ have distinct half-chair conformations again twisted on $\mathrm{C}_{4}-\mathrm{C}_{5}$. These two atoms lie between 0.10 and $0.12 \AA$ from the mean plane through the ring.

Table 2. Selected bond lengths of NHC salts with naphthyl wingtips and of known free carbenes

\begin{tabular}{|c|c|c|c|c|}
\hline Imidazolinium salt & $\mathrm{C}_{2}-\mathrm{N}_{1(3)}$ & $\mathrm{C}_{4}-\mathrm{C}_{5}$ & $\mathrm{~N}_{1(3)}-\mathrm{C}_{5(4)}$ & $\mathrm{N}_{1(3)}-\mathrm{C}_{\mathrm{Ar}}$ \\
\hline syn-(2)-SIMeNap $\mathrm{HBF}_{4}{ }^{\mathrm{a}}$ & $1.311(3), 1.311(3)$ & $1.522(5)$ & $1.485(3), 1.485(3)$ & $1.440(3), 1.440(3)$ \\
\hline anti-(2)-SICyNap $\mathrm{HBF}_{4}{ }^{\mathrm{a}}$ & $1.313(5), 1.306(5)$ & $1.536(6)$ & $1.479(5), 1.470(5)$ & $1.448(5), 1.448(5)$ \\
\hline anti-(2)-SICyheptNap $\cdot \mathrm{HBF}_{4}(\mathbf{4 c})$ & $1.308(3), 1.315(3)$ & $1.536(3)$ & $1.484(3), 1.479(3)$ & $1.444(3), 1.454(3)$ \\
\hline syn-(2,7)-SIPrNap $\cdot \mathrm{HCl}^{\mathrm{a}}$ & $1.318(4), 1.307(4)$ & $1.528(4)$ & $1.483(4), 1.481(4)$ & $1.442(4), 1.442(4)$ \\
\hline anti-(2,7)-SICyNap $\cdot \mathrm{HBF}_{4}(\mathbf{4 f})$ & $1.304(3), 1.310(3)$ & $1.542(3)$ & $1.487(2), 1.491(3)$ & $1.440(2), 1.439(3)$ \\
\hline anti-(2,7)-SICyheptNap $\cdot \mathrm{HBF}_{4}(\mathbf{4 g})$ & $1.308(4), 1.301(4)$ & $1.544(4)$ & $1.496(4), 1.490(4)$ & $1.439(4), 1.455(4)$ \\
\hline \multicolumn{5}{|l|}{ Free carbenes } \\
\hline syn-(2)-SIPrNap ${ }^{\mathrm{a}}$ & $1.351(2), 1.3498(19)$ & $1.514(2)$ & $1.4814(19), 1.486(2)$ & $1.4266(19), 1.433(2)$ \\
\hline syn-(2)-SICypentNap (5b) & $1.348(2), 1.351(2)$ & $1.520(2)$ & $1.483(2), 1.484(2)$ & $1.423(2), 1.432(2)$ \\
\hline syn-(2,7)-SIMeNap ${ }^{\mathrm{a}}$ & $1.344(4), 1.348(4)$ & $1.516(4)$ & $1.480(4), 1.480(4)$ & $1.435(4), 1.433(4)$ \\
\hline anti-(2,7)-SIPrNap $^{\mathrm{a}}$ & $1.337(3), 1.354(3)$ & $1.519(4)$ & $1.471(3), 1.473(3)$ & $1.432(4), 1.430(3)$ \\
\hline SIMes $^{b}$ & $1.352(5), 1.345(5)$ & $1.505(6)$ & $1.475(5), 1.487(5)$ & $1.427(5), 1.437(5)$ \\
\hline $\mathrm{SI}^{t} \mathrm{Bu}^{\mathrm{c}}$ & $1.348(1), 1.347(1)$ & $1.512(2)$ & $1.475(1), 1.476(1)$ & $1.480(1), 1.480(1)$ \\
\hline
\end{tabular}

${ }^{a}$ For details, see ref. $10 .{ }^{b}$ For details, see ref. $4 .{ }^{c}$ For details, see ref. $8 \mathrm{a}$. 
Table 3. Selected bond angles of NHC salts with naphthyl wingtips and of known free NHCs

\begin{tabular}{|c|c|c|c|c|}
\hline Imidazolinium salt & $\mathrm{N}_{1}-\mathrm{C}_{2}-\mathrm{N}_{3}$ & $\mathrm{C}_{5(4)}-\mathrm{N}_{1(3)}-\mathrm{C}_{2}$ & $\mathrm{~N}_{1(3)}-\mathrm{C}_{5(4)}-\mathrm{C}_{4(}$ & $\mathrm{C}_{2}-\mathrm{N}_{1(3)}-\mathrm{C}_{\mathrm{Ar}}$ \\
\hline syn-(2)-SIMeNap $\cdot \mathrm{HBF}_{4}{ }^{\mathrm{a}}$ & $113.1(3)$ & $110.5(2), 110.5(2)$ & $102.95(12), 102.95(12)$ & $128.0(2), 128.0(2)$ \\
\hline anti-(2)-SICyNap $\mathrm{HBF}_{4}{ }^{\mathrm{a}}$ & $113.4(4)$ & $110.3(3), 110.6(3)$ & $102.5(3), 102.9(3)$ & $125.2(3), 124.8(3)$ \\
\hline anti-(2)-SICyheptNap $\mathrm{HBF}_{4}(\mathbf{4 c})$ & $113.58(19)$ & $110.41(17), 110.25(17)$ & $102.63(17), 102.98(17)$ & 127.31(18), 126.28(19) \\
\hline syn-(2,7)-SIPrNap $\cdot \mathrm{HCl}^{\mathrm{a}}$ & $113.5(3)$ & $109.8(2), 109.7(2)$ & $102.1(2), 102.9(2)$ & $124.6(3), 124.8(3)$ \\
\hline anti-(2,7)-SICyNap $\cdot \mathrm{HBF}_{4}(\mathbf{4 f})$ & $114.72(18)$ & $109.98(16), 109.50(17)$ & $102.64(16), 102.73(15)$ & 124.91(16), 123.93(17) \\
\hline anti-(2,7)-SICyheptNap $\cdot \mathrm{HBF}_{4}(\mathbf{4 g})$ & $114.8(3)$ & $109.5(2), 110.3(2)$ & $102.8(2), 102.4(2)$ & $124.6(2), 124.0(2)$ \\
\hline \multicolumn{5}{|l|}{ Free carbenes } \\
\hline syn-(2)-SIPrNap ${ }^{\mathrm{a}}$ & $104.77(14)$ & $114.52(13), 114.38(13)$ & $101.25(13), 100.94(12)$ & $124.48(14), 122.38(14)$ \\
\hline syn-(2)-SICypentNap (5b) & $105.10(14)$ & $114.64(13), 114.35(14)$ & $101.17(13), 101.29(13)$ & $124.13(13), 122.60(14)$ \\
\hline syn-(2,7)-SIMeNap ${ }^{\mathrm{a}}$ & $104.8(2)$ & $115.5(2), 115.3(2)$ & $101.8(2), 101.9(2)$ & $123.6(2), 124.4(2)$ \\
\hline $\operatorname{anti-}(2,7)-\mathrm{SIPrNap}^{\mathrm{a}}$ & $104.5(2)$ & $115.9(2), 115.8(2)$ & $102.3(2), 101.5(2)$ & $125.0(2), 123.9(2)$ \\
\hline SIMes $^{b}$ & $104.7(3)$ & $115.0(3), 114.6(3)$ & $101.6(4), 101.9(4)$ & $122.9(3), 122.5(3)$ \\
\hline $\mathrm{SI}^{t} \mathrm{Bu}{ }^{\mathrm{c}}$ & $106.44(9)$ & $112.51(8), 112.91(8)$ & $101.34(9), 100.96(9)$ & $123.37(9), 123.10(8)$ \\
\hline
\end{tabular}

${ }^{\mathrm{a}}$ For details, see ref. $10 .{ }^{\mathrm{b}}$ For details, see ref. $4 .{ }^{\mathrm{c}}$ For details, see ref. $8 \mathrm{a}$.

\section{Conclusions}

A new, regioselective and scalable procedure for the synthesis of 2,7-disubstituted naphthyl rings was developed and relies on an iron-catalyzed coupling procedure involving alkylbromides and the corresponding Grignard derivatives of the naphthalene moieties. These units were then selectively brominated at low temperature to give the corresponding 1-bromonaphthalene in quantitative yield. Subsequent Buchwald-Hartwig coupling with ethylene diamine and ringclosing gave eight new imidazolinium salts. Final deprotonation proceeded smoothly and permitted a considerable extension to the family of known, stable NHC ligands featuring a saturated central N-heterocyclic backbone. Interestingly, through carefully tuning and enlarging the substituents on positions 2 or 2,7 of the naphthyl side chains, NHC molecules were generated that display a very strong preference to assume only the anti conformation. The subtle steric differences of these new structures should allow a more thorough investigation of their behavior when used as organocatalysts or as monodentate ligands in metal complexes and pertinent research on stoichiometric and catalytic activities of these species will be published in due course. 


\section{Experimental Section}

General. All reactions were carried out using standard Schlenk or glovebox (Mecaplex or Innovative Technology) techniques under a nitrogen atmosphere. All reagents were used as received unless otherwise noted. Solvents were purchased in the best quality available, degassed by purging thoroughly with nitrogen and dried over molecular sieves of appropriate size. Alternatively, they were purged with argon and passed through alumina columns in a solvent purification system (Innovative Technology). Solvents for NMR spectroscopy were degassed with nitrogen and dried over molecular sieves. NMR spectra were measured on an AV2 400 or AV2 $500 \mathrm{MHz}$ Bruker spectrometer. Chemical shifts are given in ppm. The spectra are calibrated with respect to the residual ${ }^{1} \mathrm{H}$ and ${ }^{13} \mathrm{C}$ signals of the solvent. Multiplicities are abbreviated as follows: singlet (s), doublet (d), triplet (t), quartet (q), doublet of doublet (dd), quintet (quint), septet (sept), multiplet (m), and broad (br). High-resolution electrospray ionization mass spectrosmetry was performed on a FinniganMAT 900 (Finnigan MAT95, San Jose, CA; USA) double-focusing magnetic sector mass spectrometer (geometry BE). GC-MS analysis was done on a Finnigan Voyager GC8000 Top. 4-bromo-heptane, bromocyclopentane, bromocycloheptane and bromocyclooctane were purchased from ABCR and used as received. 2,7dihydroxynaphthalene was purchased from Sigma-Aldrich and used as received.

$\left(\mathrm{FeCl}_{3}\right)_{2}(\mathrm{TMEDA})_{3}$. A partial modification of the original procedure described by Cahiez et al. ${ }^{13 a}$ was employed. In a glovebox, a one-liter flask was filled with $500 \mathrm{ml}$ of THF and then $\mathrm{FeCl}_{3}(9.73 \mathrm{~g}, 60.00 \mathrm{mmol}$ ) was added slowly as a solid (caution: reaction is exothermic and the solvent starts to boil). After $10 \mathrm{~min}$, TMEDA (10.46 g, $90.00 \mathrm{mmol})$ was added dropwise and the color changed rapidly to brown-red. This mixture was stirred for 1 hour at room temperature; in this period of time only a very small amount of precipitate was formed. The solvent was then completely evaporated and $100 \mathrm{ml}$ of pentane were added. The walls and the bottom of the flask were scratched until an orange suspension was obtained and then it was stirred for 1 hour. The solvent was decanted and the remaining solid was washed another 2 times with $100 \mathrm{ml}$ of pentane. After 12 hours under high vacuum the desired product was obtained as a yellow powder (19.50 g, 95\% yield).

2,7-Dibromonaphthalene. Workup of the reaction was modified from the known procedure described in ref. 14. A three-liter 3-neck round-bottomed flask equipped with a mechanical stirrer was charged with $\mathrm{PPh}_{3}(720.00 \mathrm{~g}, 2.75 \mathrm{~mol})$ and 1 liter of dry acetonitrile. The mixture was stirred at $70{ }^{\circ} \mathrm{C}$ until a homogeneous solution was obtained and then it was cooled to $0^{\circ} \mathrm{C}$ to form a uniform, fine suspension to which $\mathrm{Br}_{2}(120 \mathrm{ml})$ was added dropwise over the course of 1 h. 2,7-dihydroxynaphthalene $(200.00 \mathrm{~g}, 1.25 \mathrm{~mol})$ was added as a solid in portions at room temperature and the mixture was heated at $70^{\circ} \mathrm{C}$ until a homogeneous solution was formed. At this point the flask was fitted with a distillation head and it was heated until almost all the solvent was distilled. The dark red residue was heated to ca. $270{ }^{\circ} \mathrm{C}$ and then maintained at this 
temperature for $1 \mathrm{~h}$ during which time a strong $\mathrm{HBr}$ evolution was observed (trapped by means of a beaker filled with a $\mathrm{NaOH}$ solution). The dark oil was allowed to cool to ca. $140{ }^{\circ} \mathrm{C}$, poured into EtOH (2 1) and then allowed to sit overnight. The crude product was isolated by filtration and then recrystallized from ethanol. The final gray-brown solid was dried thoroughly under vacuum and then purified by filtering through a siliga gel plug (hexane as eluent) to give the title product as a white solid (148.00 g, 49\% yield). ${ }^{21}$

\section{General procedure for the iron-catalyzed C-C coupling}

2-(4-Heptyl)naphthalene (1a). In a $250 \mathrm{~mL}$ 3-necked flask, equipped with condenser, addition funnel and $\mathrm{N}_{2}$ inlet, were added magnesium (1.18 g, $48.30 \mathrm{mmol}$ ) and $\mathrm{I}_{2}$ (one crystal) under $\mathrm{N}_{2}$. In the addition funnel were charged 2-bromonaphthalene (10.00 g, $48.30 \mathrm{mmol})$ and THF (70 $\mathrm{ml})$. A small amount of this solution was added to the flask and warmed with the heat gun until the color became light brown. The reaction mixture was then heated to $60^{\circ} \mathrm{C}$ (oil bath) and the remaining 2-bromonaphthalene solution was added dropwise. At the end of the addition, the mixture was further refluxed for $1 \mathrm{~h}$. In the meantime, in a $250 \mathrm{ml}$ Schlenk flask containing $60 \mathrm{ml}$ of dry THF where charged 4-bromoheptane $(6.66 \mathrm{~g}, 37.20 \mathrm{mmol})$ and $\left(\mathrm{FeCl}_{3}\right)_{2}(\mathrm{TMEDA})_{3}(0.75$ $\mathrm{g}, 1.12 \mathrm{mmol}$ ). To this flask was then added dropwise the Grignard reagent previously generated; the resulting black mixture was stirred for $30 \mathrm{~min}$ at room temperature. The reaction was quenched with aqueous $\mathrm{HCl}\left(1 \mathrm{M}\right.$ solution) and extracted with $\mathrm{Et}_{2} \mathrm{O}(2 \times 150 \mathrm{ml})$. After evaporation of the solvent, the crude product was heated at $90{ }^{\circ} \mathrm{C}$ under high vacuum to eliminate the excess of alkyl bromide and naphthalene. The desired product was isolated after flash chromatography (eluent: hexane) as a colorless oil (7.30 g, 92\% yield). ${ }^{1} \mathrm{H} \mathrm{NMR}\left(\mathrm{CDCl}_{3}\right.$, $400 \mathrm{MHz}): \delta 7.83(\mathrm{~m}, 3 \mathrm{H}), 7.61(\mathrm{~s}, 1 \mathrm{H}), 7.52-7.42(\mathrm{~m}, 2 \mathrm{H}), 7.37(\mathrm{~m}, 1 \mathrm{H}), 2.76(\mathrm{~m}, 1 \mathrm{H}), 1.77-$ $1.64(\mathrm{~m}, 4 \mathrm{H}), 1.30-1.15(\mathrm{~m}, 4 \mathrm{H}), 0.91(\mathrm{t}, J=7.3 \mathrm{~Hz}, 6 \mathrm{H}) .{ }^{13} \mathrm{C} \mathrm{NMR}\left(\mathrm{CDCl}_{3}, 100 \mathrm{MHz}\right): \delta 144.0$, $133.9,132.5,128.1,127.9,127.8,126.6,126.3,126.0,125.2,45.9,39.4,21.1,14.4$. HRMS (EI) $\mathrm{m} / z$ calcd for $\mathrm{C}_{17} \mathrm{H}_{22}: 226.1722$. Found: 226.1722 .

2-Cyclopentylnaphthalene (1b). Following the general procedure [2-bromonaphthalene (10.00 $\mathrm{g}, 48.30 \mathrm{mmol}, 100 \mathrm{ml} \mathrm{THF}), \mathrm{Mg}(1.18 \mathrm{~g}, 48.30 \mathrm{mmol})$, catalyst (0.75 g, $1.12 \mathrm{mmol})$, bromocyclopentane $(5.54 \mathrm{~g}, 37.20 \mathrm{mmol}, 30 \mathrm{ml} \mathrm{THF})]$, the desired product was obtained after flash chromatography (eluent: hexane) as a colorless oil (4.70 g, 64\% yield). ${ }^{1} \mathrm{H} \mathrm{NMR}\left(\mathrm{CDCl}_{3}\right.$, $400 \mathrm{MHz}): \delta 7.78(\mathrm{~m}, 3 \mathrm{H}), 7.67(\mathrm{~s}, 1 \mathrm{H}), 7.43(\mathrm{~m}, 3 \mathrm{H}), 3.21(\mathrm{~m}, 1 \mathrm{H}), 2.20(\mathrm{~m}, 2 \mathrm{H}), 1.95-1.60(\mathrm{~m}$, $6 \mathrm{H}) .{ }^{13} \mathrm{C} \mathrm{NMR}\left(\mathrm{CDCl}_{3}, 100 \mathrm{MHz}\right): \delta 144.3,133.9,132.3,128.1,127.9,127.8,126.4,126.1$, 125.3, 125.1, 46.3, 34.8, 25.9. HRMS (EI) $\mathrm{m} / z$ calcd for $\mathrm{C}_{15} \mathrm{H}_{16}$ : 196.1252. Found: 196.1255.

2-Cycloheptylnaphthalene (1c). Following the general procedure [2-bromonaphthalene (10.00 $\mathrm{g}, 48.30 \mathrm{mmol}, 100 \mathrm{ml} \mathrm{THF}), \mathrm{Mg}(1.18 \mathrm{~g}, 48.30 \mathrm{mmol})$, catalyst $(0.75 \mathrm{~g}, 1.12 \mathrm{mmol})$, bromocycloheptane $(6.59 \mathrm{~g}, 48.30 \mathrm{mmol}, 50 \mathrm{ml} \mathrm{THF})]$, the desired product was obtained after flash chromatography (eluent: hexane) as a colorless oil (7.40 g, 89\% yield). ${ }^{1} \mathrm{H} \mathrm{NMR}\left(\mathrm{CDCl}_{3}\right.$, $400 \mathrm{MHz}): \delta 7.78(\mathrm{~m}, 3 \mathrm{H}), 7.62(\mathrm{~s}, 1 \mathrm{H}), 7.40(\mathrm{~m}, 3 \mathrm{H}), 2.84(\mathrm{~m}, 1 \mathrm{H}), 2.05-1.40(\mathrm{~m}, 12 \mathrm{H}) .{ }^{13} \mathrm{C}$ NMR $\left(\mathrm{CDCl}_{3}, 100 \mathrm{MHz}\right): \delta 147.7,134.0,132.2,128.1,127.9,127.8,126.4,126.0,125.2,124.6$, 47.4, 37.0, 28.3, 27.6. HRMS (EI) $m / z$ calcd for $\mathrm{C}_{17} \mathrm{H}_{20}$ : 224.1565. Found: 224.1565. 
2-Cyclooctylnaphthalene (1d). Following the general procedure [2-bromonaphthalene (15.00 g, $72.40 \mathrm{mmol}, 80 \mathrm{ml} \mathrm{THF}), \mathrm{Mg}(1.76 \mathrm{~g}, 72.40 \mathrm{mmol})$, catalyst (1.12 g, $1.67 \mathrm{mmol})$, bromocyclooctane (10.60 g, $55.70 \mathrm{mmol}, 40 \mathrm{ml} \mathrm{THF})]$, the desired product was obtained after flash chromatography (eluent: hexane) as a white solid $(9.50 \mathrm{~g}, 72 \%$ yield $) .{ }^{1} \mathrm{H} \mathrm{NMR}\left(\mathrm{CDCl}_{3}\right.$, $400 \mathrm{MHz}): \delta 7.75(\mathrm{~m}, 3 \mathrm{H}), 7.60(\mathrm{~s}, 1 \mathrm{H}), 7.39(\mathrm{~m}, 3 \mathrm{H}), 2.92(\mathrm{~m}, 1 \mathrm{H}), 1.95-1.45(\mathrm{~m}, 14 \mathrm{H}) .{ }^{13} \mathrm{C}$ NMR $\left(\mathrm{CDCl}_{3}, 100 \mathrm{MHz}\right): \delta 148.1,133.9,132.2,128.1,127.9,127.7,126.7,126.0,125.2,124.8$, 45.0, 34.8, 27.3, 26.7, 26.3. HRMS (EI): $m / z$ : calcd for $\mathrm{C}_{18} \mathrm{H}_{22}: 238.1722$. Found: 238.1725.

\section{General procedure for the iron-catalyzed double C-C coupling}

2,7-dicyclopentylnaphthalene (1e). In a $500 \mathrm{~mL}$ 3-necked flask, equipped with condenser, addition funnel and $\mathrm{N}_{2}$ inlet, were added magnesium $\left(2.40 \mathrm{~g}, 100.00 \mathrm{mmol}\right.$ ) and $\mathrm{I}_{2}$ (one crystal) under $\mathrm{N}_{2}$. In the addition funnel were charged 2,7-dibromonaphthalene (13.00 g, $\left.45.40 \mathrm{mmol}\right)$ and THF $(250 \mathrm{ml})$. A small amount of this solution was added into the flask and warmed with the heat gun until the color became light brown. The reaction mixture was then heated to $60^{\circ} \mathrm{C}$ (oil bath) and the remaining solution was added dropwise. At the end of the addition, the mixture was refluxed for another 2 hours. The obtained red-orange suspension was cooled and then cannulated, ${ }^{22}$ into a $500 \mathrm{ml}$ Schlenk flask containing bromocyclopentane (13.50 g, $\left.90.80 \mathrm{mmol}\right)$ and $\left(\mathrm{FeCl}_{3}\right)_{2}(\mathrm{TMEDA})_{3}(0.92 \mathrm{~g}, 1.57 \mathrm{mmol})$ in dry THF $(100 \mathrm{ml})$. After the addition, the resulting black mixture was stirred for 1 hour at room temperature. The reaction was then quenched with aqueous $\mathrm{HCl}\left(1 \mathrm{M}\right.$ solution) and extracted with $\mathrm{Et}_{2} \mathrm{O}$. After evaporation of the solvent, the obtained yellow oil was passed through a silica gel pad (eluent: hexane) to remove metal contaminants and give a 4:1 mixture of desired product and mono-substituted alkylnaphthalene. The latter could be eliminated by Kugelrohr distillation $\left(120-125{ }^{\circ} \mathrm{C}, 0.01\right.$ mbar). The desired product was obtained as a white solid (4.19 g, 35\% yield). ${ }^{1} \mathrm{H} \mathrm{NMR}\left(\mathrm{CDCl}_{3}\right.$, $400 \mathrm{MHz}): \delta 7.71(\mathrm{~d}, J=8.5 \mathrm{~Hz}, 2 \mathrm{H}), 7.59$ (s, 2H), 7.33 (d, J = 8.5 Hz, 2H), $3.12(\mathrm{~m}, 2 \mathrm{H}), 2.20-$ $2.00(\mathrm{~m}, 4 \mathrm{H}), 1.81-1.60(\mathrm{~m}, 12 \mathrm{H}) .{ }^{13} \mathrm{C} \mathrm{NMR}\left(\mathrm{CDCl}_{3}, 100 \mathrm{MHz}\right): \delta 144.25,133.97,130.89$, 127.7, 125.7, 124.7, 46.4, 34.8, 25.9. HRMS (EI) $\mathrm{m} / z$ calcd for $\mathrm{C}_{20} \mathrm{H}_{24}$ : 264.1878. Found: 264.1880 .

2,7-Dicyclohexylnaphthalene (1f). Following the general procedure [2,7-dibromonaphthalene (30.00 g, $105.00 \mathrm{mmol}, 500 \mathrm{ml} \mathrm{THF}), \mathrm{Mg}$ (5.61 g, $231.00 \mathrm{mmol})$, catalyst (2.12 g, $3.15 \mathrm{mmol})$, bromocyclohexane $(34.00 \mathrm{~g}, 210.00 \mathrm{mmol}, 200 \mathrm{ml}$ THF)], the desired product was obtained as a white solid (13.70 g, 45\% yield). ${ }^{1} \mathrm{H} \mathrm{NMR}\left(\mathrm{CDCl}_{3}, 400 \mathrm{MHz}\right): \delta 7.71(\mathrm{~d}, J=7.8 \mathrm{~Hz}, 2 \mathrm{H}), 7.54$ $(\mathrm{s}, 2 \mathrm{H}), 7.28(\mathrm{~d}, \mathrm{~J}=7.8 \mathrm{~Hz}, 2 \mathrm{H}), 2.64(\mathrm{~m}, 2 \mathrm{H}), 2.00-1.82(\mathrm{~m}, 10 \mathrm{H}), 1.61-1.23(\mathrm{~m}, 10 \mathrm{H}) .{ }^{13} \mathrm{C}$ NMR $\left(\mathrm{CDCl}_{3}, 100 \mathrm{MHz}\right): \delta 145.7,134.1,131.0,127.6,125.6,124.4,44.9,34.7,27.2,26.5$. HRMS (EI) $m / z$ calcd for $\mathrm{C}_{22} \mathrm{H}_{26}$ : 292.2191. Found: 292.2191.

2,7-Dicycloheptylnaphthalene (1g). Following the general procedure [2,7-dibromonaphthalene (10.00 g, $35.00 \mathrm{mmol}, 400 \mathrm{ml} \mathrm{THF}), \mathrm{Mg}$ (2.50 g, $102.88 \mathrm{mmol})$, catalyst (1.20 g, $1.78 \mathrm{mmol})$, bromocycloheptane $(12.40 \mathrm{~g}, 70.02 \mathrm{mmol}, 100 \mathrm{ml} \mathrm{THF})]$, the desired product was obtained as a white solid (3.50 g, 31\% yield). ${ }^{1} \mathrm{H} \mathrm{NMR}\left(\mathrm{CDCl}_{3}, 400 \mathrm{MHz}\right): \delta 7.72(\mathrm{~d}, J=7.8 \mathrm{~Hz}, 2 \mathrm{H}), 7.52$ (s, 2H), $7.27(\mathrm{~d}, J=7.8 \mathrm{~Hz}, 2 \mathrm{H}), 2.84(\mathrm{~m}, 2 \mathrm{H}), 2.10-1.50(\mathrm{~m}, 24 \mathrm{H}) .{ }^{13} \mathrm{C} \mathrm{NMR}\left(\mathrm{CDCl}_{3}, 100 \mathrm{MHz}\right): \delta$ 
147.6, 134.1, 130.6, 127.7, 125.5, 124.2, 47.3, 37.0, 28.3, 27.5. HRMS (EI) $m / z$ calcd for $\mathrm{C}_{24} \mathrm{H}_{32}$ : 320.2504. Found: 320.2500 .

2,7-Dicyclooctylnaphthalene (1h). Following the general procedure [2,7-dibromonaphthalene (12.00 g, $42.00 \mathrm{mmol}, 200 \mathrm{ml} \mathrm{THF}), \mathrm{Mg}$ (2.55 g, $105.00 \mathrm{mmol})$, catalyst (0.85 g, $1.26 \mathrm{mmol})$, bromocyclooctane (16.00 g, $84.00 \mathrm{mmol}, 100 \mathrm{ml} \mathrm{THF})]$, the desired product was obtained as a white solid (6.10 g, 42\% yield). ${ }^{1} \mathrm{H} \mathrm{NMR}\left(\mathrm{CDCl}_{3}, 400 \mathrm{MHz}\right): \delta 7.68(\mathrm{~d}, J=8.5 \mathrm{~Hz}, 2 \mathrm{H}), 7.52$ (s, 2H), 7.27 (d, $J=7.8 \mathrm{~Hz}, 2 \mathrm{H}), 2.89(\mathrm{~m}, 2 \mathrm{H}), 1.95-1.50$ (m, 28H). ${ }^{13} \mathrm{C} \mathrm{NMR}\left(\mathrm{CDCl}_{3}, 100 \mathrm{MHz}\right): \delta$ $148.0,134.1,130.6,127.7,125.8,124.5,45.0,34.8,27.3,26.7,26.3$. HRMS (EI) $\mathrm{m} / z$ calcd for $\mathrm{C}_{26} \mathrm{H}_{36}: 348.2817$. Found: 348.2813 .

\section{General procedure for the bromination of 2- and 2,7-alkyl substituted naphthalene}

1-Bromo-2-(4-heptyl)naphthalene (2a). Compound 1a (5.00 g, $23.55 \mathrm{mmol})$ was dissolved in $100 \mathrm{ml}$ of dry $\mathrm{CH}_{2} \mathrm{Cl}_{2}$ in a Schlenk flask and the solution was cooled to $-78^{\circ} \mathrm{C}$. At this temperature, a solution of $\mathrm{Br}_{2}(3.76 \mathrm{~g}, 23.55 \mathrm{mmol})$ in $\mathrm{CH}_{2} \mathrm{Cl}_{2}(50 \mathrm{ml})$ was added slowly. The reaction was left stirring at the same temperature for 5 hours and was subsequently quenched with aqueous $\mathrm{NaOH}$ (1M solution, $100 \mathrm{ml}$ ). The organic phase was separated, washed with 200 $\mathrm{ml}$ of water, dried with $\mathrm{MgSO}_{4}$, filtered and concentrated under vacuum to afford a orange oil. After purification on a silica gel pad (eluent: hexane) to eliminate residual $\mathrm{Br}_{2}$, the desired product was obtained as a nearly colorless oil (6.80 g, 99\% yield). ${ }^{1} \mathrm{H} \mathrm{NMR}\left(\mathrm{CDCl}_{3}, 400 \mathrm{MHz}\right)$ : $\delta 8.35(\mathrm{~d}, J=8.5 \mathrm{~Hz}, 1 \mathrm{H}), 7.78(\mathrm{~m}, 2 \mathrm{H}), 7.57(\mathrm{t}, J=8.3 \mathrm{~Hz}, 1 \mathrm{H}), 7.47(\mathrm{t}, J=8.0 \mathrm{~Hz}, 1 \mathrm{H}), 7.33$ $(\mathrm{d}, J=8.5 \mathrm{~Hz}, 1 \mathrm{H}), 3.63(\mathrm{~m}, 1 \mathrm{H}), 1.77-1.51(\mathrm{~m}, 4 \mathrm{H}), 1.34-1.08(\mathrm{~m}, 4 \mathrm{H}), 0.85(\mathrm{t}, J=7.4 \mathrm{~Hz}, 6 \mathrm{H})$.

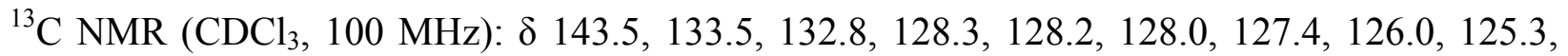
125.2, 44.2, 39.1, 20.7, 14.5. HRMS (EI) $\mathrm{m} / z$ calcd for $\mathrm{C}_{17} \mathrm{H}_{21} \mathrm{Br}$ 304.0827. Found: 304.0830.

1-Bromo-2-cyclopentylnaphthalene (2b). Following the general procedure using $\mathbf{1 b}(4.20 \mathrm{~g}$, $21.40 \mathrm{mmol}, 80 \mathrm{ml} \mathrm{CH} \mathrm{Cl}_{2}$ ) and $\mathrm{Br}_{2}\left(3.42 \mathrm{~g}, 21.40 \mathrm{mmol}, 80 \mathrm{ml} \mathrm{CH} \mathrm{Cl}_{2}\right.$ ), the desired product was obtained as a nearly colorless oil $\left(5.75 \mathrm{~g}, 98 \%\right.$ yield). ${ }^{1} \mathrm{H} \mathrm{NMR}\left(\mathrm{CDCl}_{3}, 400 \mathrm{MHz}\right): \delta 8.36$ $(\mathrm{d}, J=8.5 \mathrm{~Hz}, 1 \mathrm{H}), 7.78(\mathrm{~m}, 2 \mathrm{H}), 7.56(\mathrm{~m}, 1 \mathrm{H}), 7.45(\mathrm{~m}, 2 \mathrm{H}), 3.72$ (hept, $J=8 \mathrm{~Hz}, 1 \mathrm{H}), 2.2(\mathrm{~m}$, 2H), 1.95-1.60 (m, 6H). ${ }^{13} \mathrm{C} \mathrm{NMR}\left(\mathrm{CDCl}_{3}, 100 \mathrm{MHz}\right): \delta 143.6,133.5,132.8,128.2,128.0$, 127.9, 127.5, 126.0, 125.1, 124.2, 46.0, 34.1, 26.2. HRMS (EI) $m / z$ calcd for $\mathrm{C}_{15} \mathrm{H}_{15} \mathrm{Br}$ : 274.0357. Found: 274.0352 .

1-Bromo-2-cycloheptylnaphthalene (2c). Following the general procedure using $1 \mathrm{c}(5.70 \mathrm{~g}$, $\left.25.60 \mathrm{mmol}, 50 \mathrm{ml} \mathrm{CH} \mathrm{Cl}_{2}\right)$ and $\mathrm{Br}_{2}\left(4.09 \mathrm{~g}, 25.29 \mathrm{mmol}, 80 \mathrm{ml} \mathrm{CH}_{2} \mathrm{Cl}_{2}\right)$, the desired product was obtained as a colorless oil $(7.60 \mathrm{~g}, 99 \%$ yield $) .{ }^{1} \mathrm{H} \mathrm{NMR}\left(\mathrm{CDCl}_{3}, 400 \mathrm{MHz}\right): \delta 8.36(\mathrm{~d}, J=$ $8.5 \mathrm{~Hz}, 1 \mathrm{H}), 7.78(\mathrm{~m}, 2 \mathrm{H}), 7.58(\mathrm{~m}, 1 \mathrm{H}), 7.48(\mathrm{~m}, 1 \mathrm{H}), 7.40(\mathrm{~d}, J=8.5 \mathrm{~Hz}, 1 \mathrm{H}), 3.52(\mathrm{~m}, 1 \mathrm{H})$, 2.05-1.50 (m, 12H). ${ }^{13} \mathrm{C} \mathrm{NMR}\left(\mathrm{CDCl}_{3}, 100 \mathrm{MHz}\right): \delta 146.5,133.3,132.7,128.2,128.1,128.0$, 127.4, 125.9, 125.5, 122.8, 46.2, 35.8, 28.2, 27.9. HRMS (EI) $m / z$ calcd for $\mathrm{C}_{17} \mathrm{H}_{19} \mathrm{Br}: 302.0673$. Found: 302.0673 .

1-Bromo-2-cyclooctylnaphthalene (2d). Following the general procedure using $1 \mathrm{~d}(5.00 \mathrm{~g}$, $\left.21.00 \mathrm{mmol}, 80 \mathrm{ml} \mathrm{CH} \mathrm{Cl}_{2}\right)$ and $\mathrm{Br}_{2}\left(3.35 \mathrm{~g}, 21.00 \mathrm{mmol}, 80 \mathrm{ml} \mathrm{CH}_{2} \mathrm{Cl}_{2}\right)$, the desired product was obtained as a transparent oil (6.65 g, 99\% yield). ${ }^{1} \mathrm{H} \mathrm{NMR}\left(\mathrm{CDCl}_{3}, 400 \mathrm{MHz}\right): \delta 8.32(\mathrm{~d}, J=$ 
$8.4 \mathrm{~Hz} 2 \mathrm{H}), 7.75(\mathrm{~m}, 1 \mathrm{H}), 7.55(\mathrm{~m}, 1 \mathrm{H}), 7.44(\mathrm{~m}, 1 \mathrm{H}), 7.37(\mathrm{~d}, J=8.4 \mathrm{~Hz} 3 \mathrm{H}), 3.68(\mathrm{~m}, 1 \mathrm{H})$, 1.90-1.52 (m, 14H). ${ }^{13} \mathrm{C} \mathrm{NMR}\left(\mathrm{CDCl}_{3}, 125 \mathrm{MHz}\right): \delta 147.33,133.31,132.75,128.17,128.09$, 128.08, 127.44, 125.94, 122.87, 43.58, 34.56, 27.18, 26.88, 26.59. HRMS (EI): $\mathrm{m} / z$ : calcd for $\mathrm{C}_{18} \mathrm{H}_{21} \mathrm{Br}: 316.0827$; Found: 316.0823 .

1-Bromo-2,7-dicyclopentylnaphthalene (2e). Following the general procedure using $1 \mathrm{e}(2.13 \mathrm{~g}$, $\left.8.06 \mathrm{mmol}, 20 \mathrm{ml} \mathrm{CH} \mathrm{Cl}_{2}\right)$ and $\mathrm{Br}_{2}\left(1.29 \mathrm{~g}, 8.06 \mathrm{mmol}, 20 \mathrm{ml} \mathrm{CH}_{2} \mathrm{Cl}_{2}\right)$, the desired product was obtained as a colorless oil $\left(2.70 \mathrm{~g}, 98 \%\right.$ yield). ${ }^{1} \mathrm{H}$ NMR $\left(\mathrm{CDCl}_{3}, 400 \mathrm{MHz}\right): \delta 8.14(\mathrm{~s}, 1 \mathrm{H}), 7.68$ $(\mathrm{d}, \mathrm{J}=8.5 \mathrm{~Hz}, 2 \mathrm{H}), 7.34(\mathrm{~m}, 2 \mathrm{H}), 3.80(\mathrm{~m}, 1 \mathrm{H}), 3.20(\mathrm{~m}, 1 \mathrm{H}), 2.20-1.5(\mathrm{~m}, 16 \mathrm{H}) .{ }^{13} \mathrm{C}$ NMR $\left(\mathrm{CDCl}_{3}, 100 \mathrm{MHz}\right): \delta 146.0,143.6,132.8,132.1,128.2,127.7,126.2,125.2,124.3,123.9,46.7$, 46.0, 35.0, 34.1, 26.2 26.0. HRMS (EI) $\mathrm{m} / z$ calcd for $\mathrm{C}_{22} \mathrm{H}_{27} \mathrm{Br}: 342.0983$. Found: 342.0980 .

1-Bromo-2,7-dicyclohexylnaphthalene (2f). Following the general procedure using $\mathbf{1 f}(2.20 \mathrm{~g}$, $\left.7.52 \mathrm{mmol}, 60 \mathrm{ml} \mathrm{CH} \mathrm{Cl}_{2}\right)$ and $\mathrm{Br}_{2}\left(1.26 \mathrm{~g}, 7.90 \mathrm{mmol}, 20 \mathrm{ml} \mathrm{CH}_{2} \mathrm{Cl}_{2}\right.$ ), the desired product was obtained as a light yellow oil $\left(2.75 \mathrm{~g}, 98 \%\right.$ yield). ${ }^{1} \mathrm{H}$ NMR $\left(\mathrm{CDCl}_{3}, 400 \mathrm{MHz}\right): \delta 8.11(\mathrm{~s}, 1 \mathrm{H})$, $7.68(\mathrm{~m}, 2 \mathrm{H}), 7.34(\mathrm{~m}, 2 \mathrm{H}), 3.35(\mathrm{~m}, 1 \mathrm{H}), 2.71(\mathrm{~m}, 1 \mathrm{H}), 2.00-1.2(\mathrm{~m}, 20 \mathrm{H}) .{ }^{13} \mathrm{C} \mathrm{NMR}\left(\mathrm{CDCl}_{3}\right.$, $100 \mathrm{MHz}): \delta 147.4,144.3,132.8,132.1,128.1,127.6,126.1,124.9,124.3,123.5,45.3,44.7$, 34.7, 33.4, 27.2, 27.1, 26.5, 26.4. HRMS (EI) $\mathrm{m} / z$ calcd for $\mathrm{C}_{22} \mathrm{H}_{27} \mathrm{Br}$ : 370.1296. Found: 370.1297.

1-Bromo-2,7-dicycloheptylnaphthalene (2g). Following the general procedure using $\mathbf{1 g}$ (1.20 $\left.\mathrm{g}, 3.74 \mathrm{mmol}, 40 \mathrm{ml} \mathrm{CH} \mathrm{Cl}_{2}\right)$ and $\mathrm{Br}_{2}\left(0.59 \mathrm{~g}, 3.70 \mathrm{mmol}, 40 \mathrm{ml} \mathrm{CH}_{2} \mathrm{Cl}_{2}\right)$, the desired product was obtained as a light yellow oil (1.50 g, 99\% yield). ${ }^{1} \mathrm{H} \mathrm{NMR}\left(\mathrm{CDCl}_{3}, 400 \mathrm{MHz}\right): \delta 8.08$ (s, $1 \mathrm{H}), 7.68(\mathrm{~m}, 2 \mathrm{H}), 7.34(\mathrm{~m}, 2 \mathrm{H}), 3.51(\mathrm{~m}, 1 \mathrm{H}), 2.85(\mathrm{~m}, 1 \mathrm{H}), 2.08-1.5(\mathrm{~m}, 24 \mathrm{H}) .{ }^{13} \mathrm{C}$ NMR $\left(\mathrm{CDCl}_{3}, 100 \mathrm{MHz}\right): \delta 149.1,147.0,132.9,132.0,128.3,127.8,126.0,124.7,122.9,47.7,37.1$, 35.9, 28.3, 28,2 27.9, 27.6. HRMS (EI) $m / z$ calcd for $\mathrm{C}_{24} \mathrm{H}_{31} \mathrm{Br}$ : 398.1609. Found: 398.1610.

1-Bromo-2,7-dicyclooctylnaphthalene (2h). Following the general procedure using $\mathbf{1 h}(9.40 \mathrm{~g}$, $27.00 \mathrm{mmol}, 300 \mathrm{ml} \mathrm{CH} \mathrm{Cl}_{2}$ ) and $\mathrm{Br}_{2}\left(4.31 \mathrm{~g}, 27.00 \mathrm{mmol}, 200 \mathrm{ml} \mathrm{CH} \mathrm{Cl}_{2}\right)$, the desired product was obtained as an almost colorless oil $(11.40 \mathrm{~g}, 99 \%$ yield $) .{ }^{1} \mathrm{H}$ NMR $\left(\mathrm{CDCl}_{3}, 400 \mathrm{MHz}\right): \delta$ $8.12(\mathrm{~s}, 1 \mathrm{H}), 7.68(\mathrm{~d}, J=8.4 \mathrm{~Hz}, 2 \mathrm{H}), 7.32(\mathrm{~m}, 2 \mathrm{H}), 3.71(\mathrm{~m}, 1 \mathrm{H}), 2.98(\mathrm{~m}, 1 \mathrm{H}), 2.00-1.5(\mathrm{~m}$, 28H). ${ }^{13} \mathrm{C} \mathrm{NMR}\left(\mathrm{CDCl}_{3}, 100 \mathrm{MHz}\right): \delta 149.8,147.2,132.8,131.8,128.3,127.7,126.3,125.0$, 124.9, 122.7, 45.4, 35.0, 34.6, 27.2, 27.1, 26.9, 26.7, 26.6 HRMS (EI) $m / z$ calcd for $\mathrm{C}_{26} \mathrm{H}_{35} \mathrm{Br}$ : 426.1922. Found: 426.1916.

\section{General procedure for the $\mathrm{C}-\mathrm{N}$ Buchwald-Hartwig coupling}

$N, N^{\prime}$-Bis(2-(4-heptyl)naphthalene-1-yl)ethane-1,2-diamine (3a). In a glove box, a Schlenk flask was charged with rac-BINAP $(0.27 \mathrm{~g}, 0.42 \mathrm{mmol}), \mathrm{Pd}(\mathrm{dba})_{2}(0.23 \mathrm{~g}, 0.38 \mathrm{mmol}) \mathrm{NaO}^{t} \mathrm{Bu}$ $(1.15 \mathrm{~g}, 11.60 \mathrm{mmol})$ and toluene $(50 \mathrm{ml})$. The resulting violet suspension was stirred at room temperature for 10 minutes and then $2 \mathrm{a}(2.60 \mathrm{~g}, 8.52 \mathrm{mmol})$ was added. After another 5 minutes ethylenediamine $(0.23 \mathrm{~g}, 3.87 \mathrm{mmol})$ was added, the flask was taken out of the glovebox, connected to a condenser and the suspension was refluxed for 18 hours. The mixture was cooled to room temperature and then passed through a celite filter to eliminate the inorganic salts. After evaporation of the solvent the obtained oil was purified by silica gel chromatography (eluent: 
hexane- $\left.\mathrm{CH}_{2} \mathrm{Cl}_{2} 3: 1\right)$ to yield the desired product as a yellow oil (1.25 g, 63\% yield). ${ }^{1} \mathrm{H}$ NMR $\left(\mathrm{CDCl}_{3}, 400 \mathrm{MHz}\right): \delta 8.31(\mathrm{~d}, J=8.5 \mathrm{~Hz}, 2 \mathrm{H}), 7.79(\mathrm{~d}, J=8.1 \mathrm{~Hz}, 2 \mathrm{H}), 7.58(\mathrm{~d}, J=8.6 \mathrm{~Hz}, 2 \mathrm{H})$, 7.48-7.38 (m, 4H), $7.33(\mathrm{~d}, J=8.3 \mathrm{~Hz}, 2 \mathrm{H}), 4.05-3.85(\mathrm{~s}$, broad, $2 \mathrm{H}), 3.43(\mathrm{~s}, 4 \mathrm{H}), 3.18(\mathrm{~m}, 2 \mathrm{H})$, $1.75-1.55(\mathrm{~m}, 10 \mathrm{H}), 1.32-1.12(\mathrm{~m}, 12 \mathrm{H}), 0.85(\mathrm{t}, J=7.4 \mathrm{~Hz}, 6 \mathrm{H}) .{ }^{13} \mathrm{C} \mathrm{NMR}\left(\mathrm{CDCl}_{3}, 100 \mathrm{MHz}\right)$ : $\delta 135.00,133.32,129.7,128.4,125.8,125.3,124.9,124.2,123.9,52.0,39.5,34.9,31.8,27.1$, 25.5, 22.9, 21.4, 14.6. HRMS (ESI) $\mathrm{m} / z$ calcd for $\mathrm{C}_{30} \mathrm{H}_{48} \mathrm{~N}_{2}$ : 508.3896. Found: 509.3893 [M+1].

$\mathbf{N}, N^{\prime}$-Bis(2-cyclopentylnaphthalene-1-yl)ethane-1,2-diamine (3b). Following the general procedure [rac-BINAP $(0.41 \mathrm{~g}, 0.65 \mathrm{mmol}), \mathrm{Pd}(\mathrm{dba})_{2}(0.31 \mathrm{~g}, 0.54 \mathrm{mmol}), \mathrm{NaO}^{t} \mathrm{Bu}(1.57 \mathrm{~g}$, $16.40 \mathrm{mmol})$, Toluene (140 ml), $2 \mathrm{~b}$ (3.00 g, $10.90 \mathrm{mmol})$, ethylenediamine (0.32 g, $5.34 \mathrm{mmol})$ ], the desired product was obtained after silica gel chromatography (eluent: hexane-EtOAc 10:1) as a yellow oil $\left(2.20 \mathrm{~g}, 92 \%\right.$ yield). ${ }^{1} \mathrm{H}$ NMR $\left(\mathrm{CDCl}_{3}, 400 \mathrm{MHz}\right): \delta 8.28(\mathrm{~d}, J=8.5 \mathrm{~Hz}, 2 \mathrm{H}), 7.81$ $(\mathrm{d}, J=7.9 \mathrm{~Hz}, 2 \mathrm{H}), 7.58(\mathrm{~d}, J=8.5 \mathrm{~Hz}, 2 \mathrm{H}), 7.52-7.39(\mathrm{~m}, 6 \mathrm{H}), 3.95(\mathrm{~s}, 2 \mathrm{H}), 3.55(\mathrm{~m}, 2 \mathrm{H}), 3.45$ (s, 4H), $2.12(\mathrm{~m}, 4 \mathrm{H}), 2.00-1.70(\mathrm{~m}, 12 \mathrm{H}) .{ }^{13} \mathrm{C} \mathrm{NMR}\left(\mathrm{CDCl}_{3}, 100 \mathrm{MHz}\right): \delta 142.0,135.2,133.4$, $129.5,128.5,125.9,125.3,125.2,124.0,123.4,52.3,40.1,35.1,26.4$. HRMS (ESI) $\mathrm{m} / z$ calcd for $\mathrm{C}_{32} \mathrm{H}_{36} \mathrm{~N}_{2}$ : 448.2878. Found: 449.2945 [M+1].

$\mathbf{N}, N^{\prime}$-Bis(2-cycloheptylnaphthalene-1-yl)ethane-1,2-diamine (3c). Following the general procedure [ rac-BINAP $(0.12 \mathrm{~g}, 0.19 \mathrm{mmol}), \mathrm{Pd}(\mathrm{dba})_{2}(0.095 \mathrm{~g}, 0.16 \mathrm{mmol}), \mathrm{NaO}{ }^{t} \mathrm{Bu}(0.48 \mathrm{~g}$, $5.00 \mathrm{mmol})$, Toluene $(50 \mathrm{ml}), 2 \mathrm{c}(1.00 \mathrm{~g}, 3.30 \mathrm{mmol})$, ethylenediamine $(0.097 \mathrm{~g}, 1.62 \mathrm{mmol})]$, the desired product was obtained after silica gel chromatography (eluent: hexane-EtOAc 10:1) as a yellow foam $\left(0.71 \mathrm{~g}, 87 \%\right.$ yield). ${ }^{1} \mathrm{H} \mathrm{NMR}\left(\mathrm{CDCl}_{3}, 400 \mathrm{MHz}\right): \delta 8.28(\mathrm{~d}, J=8.5 \mathrm{~Hz}, 2 \mathrm{H}), 7.81$ $(\mathrm{d}, J=7.9 \mathrm{~Hz}, 2 \mathrm{H}), 7.58(\mathrm{~d}, J=8.5 \mathrm{~Hz}, 2 \mathrm{H}), 7.52-7.39(\mathrm{~m}, 6 \mathrm{H}), 3.90(\mathrm{~s}, 2 \mathrm{H}), 3.45(\mathrm{~s}, 4 \mathrm{H}), 3.35$ (m, 2H), 2.00-1.50 (m, 24H). ${ }^{13} \mathrm{C} \mathrm{NMR}\left(\mathrm{CDCl}_{3}, 100 \mathrm{MHz}\right): \delta 140.2,139.1,133.3,129.8,128.5$, 125.9 , 125.7, 125.2, 124.2, 123.6, 52.4, 40.7, 36.9, 28.2, 28.1. HRMS (EI) $\mathrm{m} / z$ calcd for $\mathrm{C}_{36} \mathrm{H}_{44} \mathrm{~N}_{2}$ : 504.3504. Found: 504.3511.

$\boldsymbol{N}, \boldsymbol{N}$ '-Bis(2-cyclooctylnaphthalene-1-yl)ethane-1,2-diamine (3d). Following the general procedure [rac-BINAP $(0.34 \mathrm{~g}, 0.55 \mathrm{mmol}), \mathrm{Pd}(\mathrm{dba})_{2}(0.26 \mathrm{~g}, 0.45 \mathrm{mmol}), \mathrm{NaO}^{t} \mathrm{Bu}(1.31 \mathrm{~g}$, $13.60 \mathrm{mmol})$, Toluene $(100 \mathrm{ml}), 2 \mathrm{~d}(3.17 \mathrm{~g}, 10.0 \mathrm{mmol})$, ethylenediamine $(0.27 \mathrm{~g}, 4.55 \mathrm{mmol})]$, the desired product was obtained after silica gel chromatography (eluent: hexane-EtOAc 10:1) as an off-white powder $\left(1.60 \mathrm{~g}, 66 \%\right.$ yield). ${ }^{1} \mathrm{H} \mathrm{NMR}\left(\mathrm{CDCl}_{3}, 400 \mathrm{MHz}\right): \delta 8.28$ (s, broad, $\left.2 \mathrm{H}\right)$, 7.78 (d, $J=8 \mathrm{~Hz}, 1 \mathrm{H}), 7.58$ (d, $J=8.9 \mathrm{~Hz}, 2 \mathrm{H}), 7.48-7.33$ (m, 6H), 4.20-3.50 (s, broad, 2H), $3.52(\mathrm{~m}, 6 \mathrm{H}), 1.90-1.42(\mathrm{~m}, 14 \mathrm{H}) .{ }^{13} \mathrm{C} \mathrm{NMR}\left(\mathrm{CDCl}_{3}, 100 \mathrm{MHz}\right): \delta 140.15,140.02,133.25$, 129.84, 128.49, 126.09, 125.92, 125.25, 124.25, 123.67, 52.40, 38.04, 35.62, 27.04, 26.93, 26.87. HRMS (ESI) $m / z$ calcd for $\mathrm{C}_{38} \mathrm{H}_{48} \mathrm{~N}_{2}$ : 532.3895. Found: 533.3890 [M+1].

$N, N$ '-Bis(2,7-dicyclopentylnaphthalene-1-yl)ethane-1,2-diamine (3e). Following the general procedure [rac-BINAP $(0.41 \mathrm{~g}, 0.65 \mathrm{mmol}), \mathrm{Pd}(\mathrm{dba})_{2}(0.31 \mathrm{~g}, 0.54 \mathrm{mmol}), \mathrm{NaO}^{t} \mathrm{Bu}(1.57 \mathrm{~g}$, $16.44 \mathrm{mmol})$, Toluene $(140 \mathrm{ml}), 2 \mathrm{e}(3.00 \mathrm{~g}, 10.91 \mathrm{mmol})$, ethylenediamine (0.32 g, $5.34 \mathrm{mmol})]$, the desired product was obtained after silica gel chromatography (eluent: hexane-EtOAc 20:1 to $10: 1)$ as a yellow oil $\left(2.20 \mathrm{~g}, 92 \%\right.$ yield). ${ }^{1} \mathrm{H}$ NMR $\left(\mathrm{CDCl}_{3}, 400 \mathrm{MHz}\right): \delta 8.10(\mathrm{~s}, 2 \mathrm{H}), 7.72(\mathrm{~d}, J$ $=8.4 \mathrm{~Hz}, 2 \mathrm{H}), 7.52(\mathrm{~d}, J=8.6 \mathrm{~Hz} 2 \mathrm{H}), 7.33(\mathrm{~d}, J=8.5 \mathrm{~Hz}, 4 \mathrm{H}), 3.90(\mathrm{~s}, \operatorname{broad} 2 \mathrm{H}), 3.50(\mathrm{~m}$, 2H), $3.42(\mathrm{~s}, 4 \mathrm{H}), 3.13(\mathrm{~m}, 2 \mathrm{H}), 2.15-1.60(\mathrm{~m}, 32 \mathrm{H}) .{ }^{13} \mathrm{C} \mathrm{NMR}\left(\mathrm{CDCl}_{3}, 100 \mathrm{MHz}\right): \delta 144.1$, 
$141.7,135.1,132.0,129.4,128.4,125.6,124.3,123.6,120.7,52.1,46.7,40.1,35.1,35.0,26.3$, 25.9. HRMS (EI) $m / z$ calcd for $\mathrm{C}_{42} \mathrm{H}_{52} \mathrm{~N}_{2}$ : 584.4130. Found: 585.4207 [M+1].

$\boldsymbol{N}, N^{\prime}$-Bis(2,7-dicyclohexylnaphthalene-1-yl)ethane-1,2-diamine (3f). Following the general procedure [ $r a c$-BINAP $(0.24 \mathrm{~g}, 0.39 \mathrm{mmol}), \mathrm{Pd}(\mathrm{dba})_{2}(0.20 \mathrm{~g}, 0.35 \mathrm{mmol}), \mathrm{NaO}^{t} \mathrm{Bu}(0.99 \mathrm{~g}$, $10.32 \mathrm{mmol})$, Toluene $(50 \mathrm{ml}), \mathbf{2 f}(2.90 \mathrm{~g}, 7.81 \mathrm{mmol})$, ethylenediamine $(0.21 \mathrm{~g}, 3.55 \mathrm{mmol})]$, the desired product was obtained after silica gel chromatography (eluent: hexane- $\mathrm{CH}_{2} \mathrm{Cl}_{2} 3: 1$ to $2: 1)$ as a crystalline white solid $\left(2.00 \mathrm{~g}, 88 \%\right.$ yield). ${ }^{1} \mathrm{H} \mathrm{NMR}\left(\mathrm{CDCl}_{3}, 400 \mathrm{MHz}\right): \delta 8.08(\mathrm{~s}, 2 \mathrm{H})$, $7.72(\mathrm{~d}, J=8.4 \mathrm{~Hz}, 2 \mathrm{H}), 7.52(\mathrm{~d}, J=8.5 \mathrm{~Hz} 2 \mathrm{H}), 7.33(\mathrm{~m}, 4 \mathrm{H}), 3.90(\mathrm{~s}$, broad $2 \mathrm{H}), 3.42(\mathrm{~s}, 4 \mathrm{H})$, $3.12(\mathrm{~m}, 2 \mathrm{H}), 2.63(\mathrm{~m}, 2 \mathrm{H}), 1.95-1.10(\mathrm{~m}, 40 \mathrm{H}) .{ }^{13} \mathrm{C} \mathrm{NMR}\left(\mathrm{CDCl}_{3}, 100 \mathrm{MHz}\right): \delta 145.6,141.0$, $136.7,132.0,129.7,128.3,125.5,124.4,123.6,120.4,52.2$, 45.3, 39.1, 34.8, 34.5, 27.4, 27.1, 26.5, 26.4. HRMS (EI) $\mathrm{m} / z$ calcd for $\mathrm{C}_{46} \mathrm{H}_{60} \mathrm{~N}_{2}$ : 640.4756 . Found: 641.4825 [M+1].

$\mathbf{N}, N^{\prime}$-Bis(2,7-dicycloheptylnaphthalene-1-yl)ethane-1,2-diamine (3g). Following the general procedure [rac-BINAP $(0.25 \mathrm{~g}, 0.40 \mathrm{mmol}), \mathrm{Pd}(\mathrm{dba})_{2}(0.17 \mathrm{~g}, 0.30 \mathrm{mmol}), \mathrm{NaO}^{t} \mathrm{Bu}(1.07 \mathrm{~g}$, $11.10 \mathrm{mmol})$, Toluene $(150 \mathrm{ml}), 2 \mathrm{~g}$ (2.90 g, $7.26 \mathrm{mmol})$, ethylenediamine $(0.21 \mathrm{~g}, 3.46 \mathrm{mmol})]$, the desired product was obtained after silica gel chromatography (eluent: Hexane to Hexane$\left.\mathrm{CH}_{2} \mathrm{Cl}_{2} 1: 1\right)$ as a crystalline white solid (2.11 g, 88\%). ${ }^{1} \mathrm{H}$ NMR (Acetone $\left.d_{6}{ }^{23}, 400 \mathrm{MHz}\right): \delta 8.17$ (s, 2H), 7.69 (d, $J=8.0 \mathrm{~Hz}, 2 \mathrm{H}), 7.48$ (d, $J=8.5 \mathrm{~Hz} 2 \mathrm{H}), 7.33(\mathrm{~m}, 4 \mathrm{H}), 3.76(\mathrm{~s}, 4 \mathrm{H}), 3.45$ (m, 2H), $2.69(\mathrm{~m}, 2 \mathrm{H}), 2.20-1.40(\mathrm{~m}, 48 \mathrm{H}) .{ }^{13} \mathrm{C}$ NMR (Acetone $\left.d_{6}, 100 \mathrm{MHz}\right): \delta 147.1,140.6,139.1$, 132.2 , 130.3, 128.5, 125.3, 124.8, 123.6, 120.8, 68.9, 68.8, 52.1, 47.8, 40.3, 37.2, 37.0, 28.2, 28.1, 27.4. HRMS (EI) $\mathrm{m} / z$ calcd for $\mathrm{C}_{50} \mathrm{H}_{68} \mathrm{~N}_{2}$ : 696.5382 . Found: 697.5455 [M+1].

$\boldsymbol{N}, N^{\prime}$-Bis(2,7-dicyclooctylnaphthalene-1-yl)ethane-1,2-diamine (3h). Following the general procedure [ rac-BINAP $(0.44 \mathrm{~g}, 0.70 \mathrm{mmol}), \mathrm{Pd}(\mathrm{dba})_{2}(0.34 \mathrm{~g}, 0.58 \mathrm{mmol}), \mathrm{NaO}^{t} \mathrm{Bu}(1.69 \mathrm{~g}$, $17.64 \mathrm{mmol})$, Toluene (150 ml), 2b (5.00 g, $15.72 \mathrm{mmol})$, ethylenediamine (0.34 g, $5.70 \mathrm{mmol})$ ], the desired product was obtained after silica gel chromatography (eluent: Hexane-EtOAc 15:1 to 10:1) as a yellow solid (3.50 g, 81\% yield). ${ }^{1} \mathrm{H}$ NMR $\left(\mathrm{CDCl}_{3}, 400 \mathrm{MHz}\right): \delta 8.08(\mathrm{~s}, 2 \mathrm{H}), 7.72(\mathrm{~d}$, $J=8.3 \mathrm{~Hz}, 2 \mathrm{H}), 7.52(\mathrm{~d}, J=8.5 \mathrm{~Hz} 2 \mathrm{H}), 7.38(\mathrm{~m}, 4 \mathrm{H}), 3.92(\mathrm{~s}, \operatorname{broad} 2 \mathrm{H}), 3.45(\mathrm{~s}, 6 \mathrm{H}), 2.89(\mathrm{~m}$, 2H), 1.95-1.10 (m, 56H). ${ }^{13} \mathrm{C} \mathrm{NMR}\left(\mathrm{CDCl}_{3}, 100 \mathrm{MHz}\right): \delta 147.8,139.9,139.8,131.7,129.9$, 128.4, 125.8, 125.1, 123.8, 120.5, 52.3, 45.5, 38.0, 35.6, 34.7, 27.3, 27.0, 26.9, 26.8, 26.4, 26.3. HRMS (EI) $m / z$ calcd for $\mathrm{C}_{54} \mathrm{H}_{76} \mathrm{~N}_{2}$ : 752.6008. Found: 752.6005 .

\section{Synthesis of imidazolinium salts}

1,3-Bis(2-(4-heptyl)naphthalen-1-yl)-imidazolinium tetrafluoroborate (4a). To a Schlenk tube containing 3a $(1.10 \mathrm{~g}, 2.16 \mathrm{mmol})$ and $\mathrm{NH}_{4} \mathrm{BF}_{4}(0.36 \mathrm{~g}, 3.46 \mathrm{mmol})$, was added $(\mathrm{EtO}){ }_{3} \mathrm{CH}$ $(20 \mathrm{ml})$. To this suspension was added formic acid ( 3 drops) and the mixture was heated at $110^{\circ} \mathrm{C}$ for 2 hours. After this time a small amount of white solid was present in the suspension. The solvent was distilled out and the obtained brown foam was purified by silica gel chromatography (eluent: Hexane to $\mathrm{CH}_{2} \mathrm{Cl}_{2}$ to $\mathrm{CH}_{2} \mathrm{Cl}_{2}-\mathrm{MeOH}$ 40:1). To the obtained light yellow oil were added ether $(3 \mathrm{ml})$ and pentane $(10 \mathrm{ml})$ to induce the precipitation of a white powder that, from NMR analysis, proved to be the desired compound (1.31 g, 75\% yield). From NMR analysis a 43:57 mixture of the two isomers was detected. ${ }^{1} \mathrm{H}$ NMR (DMSO- $d_{6}, 400 \mathrm{MHz}$ ): $\delta 9.52$ (s 1H), 8.18 (d, 
$J=8.7 \mathrm{~Hz}, 1 \mathrm{H}), 8.10(\mathrm{~d}, J=8.1 \mathrm{~Hz}, 1 \mathrm{H}), 7.92(\mathrm{~d}, J=8.4 \mathrm{~Hz}, 1 \mathrm{H}), 7.79(\mathrm{t}, J=7.2 \mathrm{~Hz}, 1 \mathrm{H}), 7.75$ $(\mathrm{d}, J=8.7 \mathrm{~Hz}, 1 \mathrm{H}), 7.68(\mathrm{~m}, 1 \mathrm{H}), 7.58(\mathrm{~m}, 1 \mathrm{H}), 7.45(\mathrm{~d}, J=7.7 \mathrm{~Hz}, 2 \mathrm{H}), 4.85-4.45(\mathrm{~m}, 4 \mathrm{H}), 3.35$ $(\mathrm{m}, 2 \mathrm{H}), 3.12(\mathrm{~m}, 1 \mathrm{H}), 2.91(\mathrm{~m}, 1 \mathrm{H}), 1.95-1.2(\mathrm{~m}, 22 \mathrm{H})$. (Due to the existence of two atropisomers, ${ }^{13} \mathrm{C}$ NMR spectrum appeared complex) ${ }^{13} \mathrm{C}$ NMR (DMSO- $\left.d_{6}, 100 \mathrm{MHz}\right): \delta 161.9$, $146.1,146.0,143.1,132.4,131.2,130.9,130.0,129.3,128.9,128.7,128.5,128.2,127.2,126.8$, 125.1, 124.9, 124.8, 121.1, 54.0, 53.1, 33.9, 32.5, 28.2, 26.2, 26.0, 25.2, 25.0, 24.8, 23.5, 23.0. ${ }^{19}$ F NMR (DMSO- $d_{6}, 376 \mathrm{MHz}$ ): $\delta-148.29,-148.35$. HRMS (ESI) $m / z$ calcd for $\mathrm{C}_{37} \mathrm{H}_{47} \mathrm{BF}_{4} \mathrm{~N}_{2}$ : 606.3768. Found: $519.3798\left[\mathrm{M}-\mathrm{BF}_{4}\right]$.

1,3-Bis(2-cyclopentylnaphthalen-1-yl)-imidazolinium tetrafluoroborate (4b). To a Schlenk tube under nitrogen containing $\mathbf{3 b}(2.20 \mathrm{~g}, 4.90 \mathrm{mmol})$ and $\mathrm{NH}_{4} \mathrm{BF}_{4}(0.64 \mathrm{~g}, 5.88 \mathrm{mmol})$, were added $(\mathrm{EtO}){ }_{3} \mathrm{CH}(20 \mathrm{ml})$ and formic acid (3 drops). The mixture was then heated at $110^{\circ} \mathrm{C}$ for 5 hours. After this the resulting suspension was cooled to room temperature and filtered to eliminate most of the $(\mathrm{EtO})_{3} \mathrm{CH}$. The obtained yellow solid was dissolved in $\mathrm{CH}_{2} \mathrm{Cl}_{2}$ and filtered through celite to eliminate the excess of $\mathrm{NH}_{4} \mathrm{BF}_{4}$. The filtrate was concentrated under vacuum until a yellow oil was obtained. Toluene $(70 \mathrm{ml})$ was then added and the obtained mixture was sonicated for 15 minutes at room temperature and then heated at $75^{\circ} \mathrm{C}$ until a homogeneous yellow suspension was formed. It was cooled to ca. $50^{\circ} \mathrm{C}$ and filtered. The obtained solid was washed with $10 \mathrm{ml}$ of $\mathrm{Et}_{2} \mathrm{O}$ and dried under high vacuum overnight ( $1.75 \mathrm{~g}, 65 \%$ yield). From NMR analysis a ca. 50:50 mixture of syn-anti isomer was observed. ${ }^{1} \mathrm{H}$ NMR (DMSO- $d_{6}, 400$ MHz): $\delta 9.58-9.52(\mathrm{~s}, 1 \mathrm{H}), 8.30(\mathrm{~d}, J=8.5 \mathrm{~Hz}, 1 \mathrm{H}), 8.18(\mathrm{~d}, J=8.7 \mathrm{~Hz}, 2 \mathrm{H}), 8.1(\mathrm{~m}, 3 \mathrm{H}), 7.83$ $(\mathrm{m}, 1 \mathrm{H}), 7.78(\mathrm{~m}, 1 \mathrm{H}), 7.70(\mathrm{~m}, 4 \mathrm{H}), 4.95-4.65(\mathrm{~m}, 4 \mathrm{H}), 3.60(\mathrm{~m}, 1 \mathrm{H}), 3.40(\mathrm{~m}, 1 \mathrm{H}), 2.28(\mathrm{~m}$, $2 \mathrm{H}), 2.10-1.50(\mathrm{~m}, 16 \mathrm{H})$. (Due to the existence of two atropisomers, ${ }^{13} \mathrm{C} \mathrm{NMR}$ spectrum appeared complex) ${ }^{13} \mathrm{C}$ NMR (DMSO- $\left.d_{6}, 100 \mathrm{MHz}\right): \delta 161.6,161.4,142.3,142.2,132.4,132.3$, $131.1,131.0,129.3,129.1,128.7,128.6,128.5,128.3,128.2,128.1,126.8,125.1,125.0,122.0$, 121.4, 53.7, 53.6, 40.1 (overlapped with solvent, determined by 2D-HSQC), 39.7 (overlapped with solvent, determined by 2D-HSQC), 36.0, 35.5, 34.7, 33.8, 26.1, 25.9, 25.8, 25.7. ${ }^{19} \mathrm{~F}$ NMR (DMSO- $d_{6}, 376 \mathrm{MHz}$ ): -148.30, -148.35. HRMS (ESI) $m / z$ calcd for $\mathrm{C}_{33} \mathrm{H}_{35} \mathrm{BF}_{4} \mathrm{~N}_{2}: 546.2829$. Found: $459.2795\left[\mathrm{M}-\mathrm{BF}_{4}\right]$.

1,3-Bis(2-cycloheptylnaphthalen-1-yl)-imidazolinium tetrafluoroborate (4c). To a Schlenk tube under nitrogen containing $3 \mathbf{c}(0.71 \mathrm{~g}, 1.41 \mathrm{mmol})$ and $\mathrm{NH}_{4} \mathrm{BF}_{4}(0.16 \mathrm{~g}, 1.55 \mathrm{mmol})$, were added $(\mathrm{EtO}){ }_{3} \mathrm{CH}(7 \mathrm{ml})$ and formic acid $\left(2\right.$ drops). The mixture was then heated at $120^{\circ} \mathrm{C}$ for 3 hours. The resulting suspension was cooled to room temperature and filtered to eliminate most of the $(\mathrm{EtO})_{3} \mathrm{CH}$. The obtained yellow solid was dissolved in $\mathrm{CH}_{2} \mathrm{Cl}_{2}$ and filtered through celite to eliminate the excess of $\mathrm{NH}_{4} \mathrm{BF}_{4}$. The solution was then concentrated under vacuum and, upon addition of $\mathrm{Et}_{2} \mathrm{O}$, a white powder precipitated. The solvent was decanted and the solid was washed with cold $\mathrm{Et}_{2} \mathrm{O}(2 \times 20 \mathrm{ml})$ and with cold $\mathrm{CH}_{2} \mathrm{Cl}_{2}(1 \times 10 \mathrm{ml})$. The desired product was dried under high vacuum for 12 hours $(0.49 \mathrm{~g}, 58 \%$ yield $)$. From NMR analysis $22 \%$ of the $s y n$ isomer was detected. ${ }^{1} \mathrm{H}$ NMR (DMSO- $\left.d_{6}, 400 \mathrm{MHz}\right): \delta 9.68-9.56(\mathrm{~s}, 1 \mathrm{H}), 8.23-8.04(\mathrm{~m}, 6 \mathrm{H})$, $7.88-7.68(\mathrm{~m}, 6 \mathrm{H}), 7.87(\mathrm{~s}, 2 \mathrm{H}), 5.05-4.65(\mathrm{~m}, 4 \mathrm{H}), 3.10-3.00(\mathrm{~m}, 2 \mathrm{H}), 2.10-1.50(\mathrm{~m}, 24 \mathrm{H})$. 
(Due to the existence of two atropisomers, ${ }^{13} \mathrm{C}$ NMR spectrum appeared complex) ${ }^{13} \mathrm{C}$ NMR (DMSO- $d_{6}, 100 \mathrm{MHz}$ ): $\delta$ 162.6, 162.0, 145.7, 145.3, 132.8, 132.7, 131.7, 131.6, 129.6, 129.5, $129.2,129.1,128.7,127.3,127.2,126.8,126.5,125.9,125.8,122.2,122.0,54.3,54.1,41.8,41.1$, 36.6, 36.2, 35.9, 35.6, 28.2, 29.0, 27.9, 27.7, 27.6, 27.4, 27.3. ${ }^{19}$ F NMR (DMSO- $d_{6}, 376 \mathrm{MHz}$ ): 148.28, -148.33. HRMS (ESI) $m / z$ calcd for $\mathrm{C}_{37} \mathrm{H}_{43} \mathrm{BF}_{4} \mathrm{~N}_{2}$ : 602.3455. Found: 515.3418 [M-BF 4 ].

1,3-Bis(2-cyclooctylnaphthalen-1-yl)-imidazolinium tetrafluoroborate (4d). To a Schlenk tube under nitrogen containing $3 \mathbf{d}(1.50 \mathrm{~g}, 2.81 \mathrm{mmol})$ and $\mathrm{NH}_{4} \mathrm{BF}_{4}(0.36 \mathrm{~g}, 3.38 \mathrm{mmol})$, were added $(\mathrm{EtO})_{3} \mathrm{CH}(30 \mathrm{ml})$ and formic acid (3 drops). The mixture was heated at $100^{\circ} \mathrm{C}$ for 2 hours. The suspension was then cooled to room temperature and filtered to eliminate most of the $(\mathrm{EtO})_{3} \mathrm{CH}$. The obtained solid was washed with $30 \mathrm{ml}$ of $\mathrm{Et}_{2} \mathrm{O}$, then dissolved in $\mathrm{CH}_{2} \mathrm{Cl}_{2}(200$ $\mathrm{ml})$ and slowly filtered through celite. The solvent was then reduced to $\sim 5 \mathrm{ml}$ and $\mathrm{Et}_{2} \mathrm{O}(60 \mathrm{ml})$ was added inducing the precipitation of a white powder. The solid was isolated by decantation and dried under high vacuum (1.53 g, 86\% yield). From NMR analysis, two isomers are present in a 83:17 (anti-syn) ratio. Due to overlap of most of the signals of the respective isomers only the ones related to the major isomer will be presented. ${ }^{1} \mathrm{H}$ NMR (DMSO- $\left.d_{6}, 400 \mathrm{MHz}\right): \delta 9.64$ (s, $1 \mathrm{H}), 8.18$ (d, $J=8.8 \mathrm{~Hz}, 2 \mathrm{H}), 8.12$ (d, $J=7.6 \mathrm{~Hz}, 2 \mathrm{H}), 8.01$ (d, $J=8.4 \mathrm{~Hz}, 2 \mathrm{H}), 7.80-7.67$ (m, $6 \mathrm{H}), 5.75(\mathrm{~s}, 4 \mathrm{H}), 5.10-4.65(\mathrm{~m}, 4 \mathrm{H}), 3.20(\mathrm{~m}, 2 \mathrm{H}), 2.15-1.50(\mathrm{~m}, 28 \mathrm{H})$. (Due to the existence of two atropisomers, ${ }^{13} \mathrm{C}$ NMR spectrum appeared complex). ${ }^{13} \mathrm{C}$ NMR (DMSO- $d_{6}, 100 \mathrm{MHz}$ ): $\delta$ $161.45,161.43,146.06,145.04,132.30,132.20,131.21,129.08,128.98,128.72,128.61,128.20$, $126.82,126.70,126.28,125.75,125.65,125.58,121.54,121.26,53.80,53.63,34.82,34.15$, $33.16,27.09,26.86,26.15,26.11,26.02,25.92,25.69,25.45,25.28,25.14 .{ }^{19} \mathrm{~F}$ NMR (DMSO- $d_{6}$, $376 \mathrm{MHz}$ ): -143.51, -143.56. HRMS (ESI) $\mathrm{m} / \mathrm{z}$ calcd for $\mathrm{C}_{39} \mathrm{H}_{47} \mathrm{BF}_{4} \mathrm{~N}_{2}$ : 630.3768. Found: $543.3727\left[\mathrm{M}-B F_{4}\right]$.

1,3-Bis(2,7-dicyclopentylnaphthalen-1-yl)-imidazolinium tetrafluoroborate (4e). To a Schlenk tube under nitrogen, containing 3e (1.60 g, $2.74 \mathrm{mmol})$ and $\mathrm{NH}_{4} \mathrm{BF}_{4}(0.45 \mathrm{~g}, 4.10$ $\mathrm{mmol})$, were added (EtO) ${ }_{3} \mathrm{CH}(30 \mathrm{ml})$ and formic acid (2 drops). The mixture was then heated at $110^{\circ} \mathrm{C}$ for 4 hour. After this it was cooled to room temperature and filtered to eliminate most of the $(\mathrm{EtO})_{3} \mathrm{CH}$. The obtained yellow solid was dissolved in $\mathrm{CH}_{2} \mathrm{Cl}_{2}$ and filtered through celite to eliminate the excess of $\mathrm{NH}_{4} \mathrm{BF}_{4}$. The solution was then concentrated in vacuum and, upon addition of $\mathrm{Et}_{2} \mathrm{O}$, a white powder precipitate. The solvent was decanted and the solid was washed with $\mathrm{Et}_{2} \mathrm{O}(3 \times 10 \mathrm{ml})$. The desired product was then dried in high vacuum for $12 \mathrm{~h}(0.73 \mathrm{~g}, 39 \%$ yield). Crystals suitable for X-Ray analysis were obtained through slow evaporation of a toluene$\mathrm{CH}_{2} \mathrm{Cl}_{2}$ solution of the product. ${ }^{1} \mathrm{H}$ NMR (DMSO- $\left.d_{6}, 400 \mathrm{MHz}\right): \delta 9.49$ (s $\left.1 \mathrm{H}\right), 8.13(\mathrm{~d}, J=8.7$ $\mathrm{Hz}, 2 \mathrm{H}), 8.07$ (d, $J=8.6 \mathrm{~Hz}, 2 \mathrm{H}), 7.87$ (s, 2H), 7.65 (m, 4H), 5.10-4.60 (m, 4H), 2.90 (m, 4H), 2.10-1.10 (m, 32H). ${ }^{13} \mathrm{C}$ NMR (DMSO- $\left.d_{6}, 100 \mathrm{MHz}\right): \delta 160.9,148.1,143.0,131.1,130.5,129.2$, $128.7,126.9,126.0,124.2,118.8,64.9,53.6,44.8,33.9,33.6,33.4,33.1,26.4,26.3,26.2,25.5$, 25.4, 15.1. ${ }^{19} \mathrm{~F}$ NMR (DMSO- $\left.d_{6}, 376 \mathrm{MHz}\right):-143.53,-143.58$. HRMS (ESI) $m / z$ calcd for $\mathrm{C}_{43} \mathrm{H}_{51} \mathrm{BF}_{4} \mathrm{~N}_{2}$ : 682.4081. Found: 595.4047 [M-BF 4 .

1,3-Bis(2,7-dicyclohexylnaphthalen-1-yl)-imidazolinium tetrafluoroborate (4f). To a Schlenk tube containing $3 f(0.96 \mathrm{~g}, 1.50 \mathrm{mmol})$ and $\mathrm{NH}_{4} \mathrm{BF}_{4}(0.19 \mathrm{~g}, 1.80 \mathrm{mmol})$, were added $(\mathrm{EtO})_{3} \mathrm{CH}$ 
$(20 \mathrm{ml})$ and formic acid (3 drops). The mixture was then heated at $110^{\circ} \mathrm{C}$ for 1 hour. After this the suspension was cooled to room temperature and filtered to eliminate most of the $(\mathrm{EtO})_{3} \mathrm{CH}$. The obtained yellow solid was dissolved in $\mathrm{CH}_{2} \mathrm{Cl}_{2}$ and filtered through celite to eliminate the excess of $\mathrm{NH}_{4} \mathrm{BF}_{4}$. The solution was then concentrated under vacuum and, upon addition of $\mathrm{Et}_{2} \mathrm{O}$, a white powder precipitated. The solvent was decanted and the solid was washed with $\mathrm{Et}_{2} \mathrm{O}(3 \times 10 \mathrm{ml})$. The desired product was then dried under high vacuum for 12 hours $(0.55 \mathrm{~g}$, $50 \%$ yield). Crystals suitable for X-Ray analysis were obtained through slow evaporation of a Toluene/ $\mathrm{CH}_{2} \mathrm{Cl}_{2}$ solution of the product. ${ }^{1} \mathrm{H}$ NMR (DMSO- $d_{6}, 400 \mathrm{MHz}$ ): $\delta 9.49$ (s $\left.1 \mathrm{H}\right), 8.13$ (d, $J=8.7 \mathrm{~Hz}, 2 \mathrm{H}), 8.07$ (d, $J=8.6 \mathrm{~Hz}, 2 \mathrm{H}), 7.87(\mathrm{~s}, 2 \mathrm{H}), 7.65(\mathrm{~m}, 4 \mathrm{H}), 5.10-4.60(\mathrm{~m}, 4 \mathrm{H}), 2.90(\mathrm{~m}$, 4H), $2.10-1.10(\mathrm{~m}, 40 \mathrm{H}) .{ }^{13} \mathrm{C}$ NMR (DMSO- $\left.d_{6}, 100 \mathrm{MHz}\right): \delta 160.9,148.1,143.0,131.1,130.5$, 129.2, 128.7, 126.9, 126.0, 124.2, 118.8, 64.9, 53.6, 44.8, 33.9, 33.6, 33.4, 33.1, 26.4, 26.3, 26.2, 25.5, 25.4, 15.1. ${ }^{19} \mathrm{~F}$ NMR (DMSO- $d_{6}, 376 \mathrm{MHz}$ ): -143.53, -143-58. HRMS (ESI) $\mathrm{m} / z$ calcd for $\mathrm{C}_{47} \mathrm{H}_{59} \mathrm{BF}_{4} \mathrm{~N}_{2}$ : 738.4707. Found: $651.4668\left[\mathrm{M}-\mathrm{BF}_{4}\right]$.

1,3-Bis(2,7-dicycloheptylnaphthalen-1-yl)-imidazolinium tetrafluoroborate (4g). Following the same procedure used to synthesize compound $\mathbf{4 a}\left[\mathbf{3 g}(1.04 \mathrm{~g}, 1.50 \mathrm{mmol}), \mathrm{NH}_{4} \mathrm{BF}_{4}(0.19 \mathrm{~g}\right.$, $1.80 \mathrm{mmol})$, formic acid (cat.), $\left.(\mathrm{EtO})_{3} \mathrm{CH}(25 \mathrm{ml})\right]$, the desired product was obtained after silica gel chromatography $\left(\mathrm{CH}_{2} \mathrm{Cl}_{2}\right.$ to $\mathrm{CH}_{2} \mathrm{Cl}_{2}-\mathrm{MeOH} 30: 1$ as eluent) as a white solid $(0.57 \mathrm{~g}, 48 \%$ yield). From NMR analysis $10 \%$ of the syn isomer was detected. Crystals suitable for X-Ray analysis were obtained by heating a suspension of the product in toluene- $\mathrm{CH}_{2} \mathrm{Cl}_{2}$ until complete dissolution and slowly cooling the sample to room temperature. ${ }^{1} \mathrm{H} \mathrm{NMR}\left(\mathrm{CDCl}_{3}, 500 \mathrm{MHz}\right): \delta$ $7.94(\mathrm{~d}, J=8.4 \mathrm{~Hz}, 2 \mathrm{H}), 7.87(\mathrm{~d}, J=8.4 \mathrm{~Hz}, 2 \mathrm{H}), 7.71(\mathrm{~s}, 1 \mathrm{H}), 7.62(\mathrm{~s}, 2 \mathrm{H}), 7.54(\mathrm{~m}, 2 \mathrm{H}), 7.45$ $(\mathrm{d}, J=8.2 \mathrm{~Hz}, 2 \mathrm{H}), 5.22-4.71(\mathrm{~m}, 4 \mathrm{H}), 2.98(\mathrm{~m}, 4 \mathrm{H}), 2.10-1.40(\mathrm{~m}, 48 \mathrm{H}) .{ }^{13} \mathrm{C} \mathrm{NMR}\left(\mathrm{CDCl}_{3}, 125\right.$ $\mathrm{MHz}): \delta 158.3,151.6,145.0,131.8,131.5,129.6,129.5,126.6,125.4,124.1,117.8,54.7,48.4$, 42.6, 37.8, 37.2, 37.1, 37.0, 36.7, 28.5, 28.3, 28.1, 28.0, 27.4, 27.3. ${ }^{19} \mathrm{~F}$ NMR (DMSO- $d_{6}, 376$ $\mathrm{MHz}$ ): $\delta$-143.49, -143.54. HRMS (EI) $m / z$ calcd for $\mathrm{C}_{51} \mathrm{H}_{67} \mathrm{BF}_{4} \mathrm{~N}_{2}$ : 707.5304. Found: 707.5305.

1,3-Bis(2,7-dicyclooctylnaphthalen-1-yl)-imidazolinium tetrafluoroborate (4h). To a Schlenk tube containing $3 \mathbf{h}(0.41 \mathrm{~g}, 0.54 \mathrm{mmol})$ and $\mathrm{NH}_{4} \mathrm{BF}_{4}(0.006 \mathrm{~g}, 0.60 \mathrm{mmol})$, were added $(\mathrm{EtO})_{3} \mathrm{CH}(6 \mathrm{ml})$ and formic acid $\left(2\right.$ drops). The mixture was then heated to $110^{\circ} \mathrm{C}$ for 4 hours and to $90^{\circ} \mathrm{C}$ overnight. The suspension was cooled to room temperature and filtered to eliminate most of the $(\mathrm{EtO})_{3} \mathrm{CH}$. The obtained yellow solid was dissolved in $\mathrm{CH}_{2} \mathrm{Cl}_{2}$ and filtered through celite to eliminate the excess of $\mathrm{NH}_{4} \mathrm{BF}_{4}$. The solution was then concentrated under vacuum and, upon addition of $\mathrm{Et}_{2} \mathrm{O}$, a white solid precipitated. The solution was decanted and the solid was washed with $\mathrm{Et}_{2} \mathrm{O}(3 \times 10 \mathrm{ml})$. The desired product was then dried under high vacuum for 12 hours (0.13 g, 29\% yield). From ${ }^{1} \mathrm{H}-\mathrm{NMR}$ analysis the two isomers were present in a ratio of 9:1 (anti/syn). Due to overlap of most of the signals of the two isomers only the ones related to the major isomer are reported. ${ }^{1} \mathrm{H}$ NMR (DMSO- $\left.d_{6}, 500 \mathrm{MHz}\right): \delta 7.99(\mathrm{~d}, J=8.3 \mathrm{~Hz}, 2 \mathrm{H}), 7.92(\mathrm{~d}, J$ $=8.7 \mathrm{~Hz}, 2 \mathrm{H}), 7.76(\mathrm{~s}, 1 \mathrm{H}), 7.64(\mathrm{~s}, 2 \mathrm{H}), 7.58(\mathrm{~d}, J=8.7 \mathrm{~Hz}, 2 \mathrm{H}), 7.52(\mathrm{~d}, J=8.5 \mathrm{~Hz}, 2 \mathrm{H}), 5.22-$ $4.75(\mathrm{~m}, 4 \mathrm{H}), 3.10(\mathrm{~s}, 4 \mathrm{H}), 2.20-1.50(\mathrm{~m}, 56 \mathrm{H}) .{ }^{13} \mathrm{C}$ NMR (DMSO-d, $\left.125 \mathrm{MHz}\right): \delta 158.4,152.3$, $145.0,131.6,131.5,129.8,129.4,127.1,125.8,124.6,118.0,54.8,46.7,41.7,35.4,35.0$, 34.2, 
33.9, 28.2, 27.7, 27.5, 27.0, 26.4, 26.3, 26.1, 25.9, 24.7. ${ }^{19} \mathrm{~F}$ NMR (DMSO- $d_{6}, 376 \mathrm{MHz}$ ): 152.63, -152.69. HRMS (ESI) $m / z$ calcd for $\mathrm{C}_{55} \mathrm{H}_{75} \mathrm{BF}_{4} \mathrm{~N}_{2}$ : 850.5959. Found: 763.5917 [M-BF $\mathrm{B}_{4}$.

\section{General procedure for the synthesis of free carbenes}

1,3-Bis(2-(4-heptyl)naphthalen-1-yl)-imidazolin-2-ylidene (5a). To a suspension of $\mathbf{4 a}(0.500$ $\mathrm{g}, 0.82 \mathrm{mmol})$ in dry THF $(50 \mathrm{ml})$ under nitrogen, $\mathrm{NaH}$ (55 to $65 \%$ suspension in mineral oil, $0.043 \mathrm{~g}, 1.07 \mathrm{mmol}$ ) and a catalytic amount of $\mathrm{KO}^{t} \mathrm{Bu}$ were added. The resulting mixture was stirred at room temperature for $15 \mathrm{~h}$. It was then slowly filtered through celite to eliminate the inorganic salts. After evaporation of the solvent, the desired product was obtained as a slightly orange solid (0.424 g, 99\% yield). From NMR analysis two distinct isomers were present in a ratio of approximately 43:57. ${ }^{1} \mathrm{H}$ NMR $\left(\mathrm{C}_{6} \mathrm{D}_{6}, 400 \mathrm{MHz}\right): \delta 8.38-8.26(\mathrm{~m}, 2 \mathrm{H}), 7.75-7.64(\mathrm{~m}$, $4 \mathrm{H})$, 7.57-7.44 (m, 2H), 7.43-7.27 (m, 4H), 3.85-3.51 (m, 6H), 1.91-1.13 (m, 16H), 1.05- 0.73 $(\mathrm{m}, 12 \mathrm{H}) .{ }^{13} \mathrm{C}$ NMR $\left(\mathrm{C}_{6} \mathrm{D}_{6}, 100 \mathrm{MHz}\right): \delta 247.2,247.1,142.5,142.2,138.6,138.5,134.1,133.0$, $132.7,129.0,128.9,127.2,126.9,126.1,126.0,125.4,125.3,124.6,124.5,53.4,54.2,40.2,40.0$, $39.9,39.8,39.738 .9,22.4,22.3,21.7,21.6,15.4,15.2,15.1$.

1,3-Bis(2-cyclopentylnaphthalen-1-yl)-imidazolin-2-ylidene $\mathbf{( 5 b ) . ~ F o l l o w i n g ~ t h e ~ g e n e r a l ~}$ procedure [4b (0.180 g, $0.27 \mathrm{mmol}), \mathrm{NaH}(0.013 \mathrm{~g}, 0.33 \mathrm{mmol}), \mathrm{KO}^{t} \mathrm{Bu}$ (cat.), THF (40 ml)], the desired compound was obtained as an off-white solid ( $0.112 \mathrm{~g}, 90 \%$ yield). From NMR analysis two isomers in a 50:50 ratio can be identified. Crystals suitable for X-Ray analysis were obtained through slow diffusion of pentane into a concentrated solution of the product in benzene. ${ }^{1} \mathrm{H}$ $\operatorname{NMR}\left(\mathrm{C}_{6} \mathrm{D}_{6}, 500 \mathrm{MHz}\right): \delta 8.32(\mathrm{~d}, J=8.3 \mathrm{~Hz}, 1 \mathrm{H}), 8.20(\mathrm{~d}, J=8.3 \mathrm{~Hz}, 1 \mathrm{H}), 7.68(\mathrm{~m}, 4 \mathrm{H}), 7.52-$ $7.42(\mathrm{~m}, 2 \mathrm{H}), 7.40-7.28(\mathrm{~m}, 4 \mathrm{H}), 3.85-3.40(\mathrm{~m}, 6 \mathrm{H}), 2.35(\mathrm{~m}, 2 \mathrm{H}), 2.17-2.00(\mathrm{~m}, 2 \mathrm{H}), 1.95-1.5$ $(\mathrm{m}, 12 \mathrm{H}) .{ }^{13} \mathrm{C}$ NMR $\left(\mathrm{C}_{6} \mathrm{D}_{6}, 125 \mathrm{MHz}\right): \delta 246.4,246.2,142.2,142.1,138.2,138.1,134.0,132.7$, $132.6,128.9,128.8,128.7,128.5,127.3,127.0,126.0,125.9,125.7,125.6,124.4,124.0,54.1$, 54.0, 41.7, 41.3, 36.3, 36.1, 35.7, 35.2, 27.4, 27.0, 26.9, 26.7.

1,3-Bis(2-cycloheptylnaphthalen-1-yl)-imidazolin-2-ylidene $\mathbf{( 5 c )}$. Following the general procedure starting [4c $(0.100 \mathrm{~g}, 0.17 \mathrm{mmol}), \mathrm{NaH}(0.008 \mathrm{~g}, 0.20 \mathrm{mmol}), \mathrm{KO}^{t} \mathrm{Bu}$ (cat.), THF (50 $\mathrm{ml})$ ], the desired compound was obtained as an off-white solid ( $0.090 \mathrm{~g}$, 99\% yield). From NMR analysis $16 \%$ of the syn isomer can be identified (due to strong overlap between most of the signals of the two isomers only the ones related to the major isomer are reported). ${ }^{1} \mathrm{H}$ NMR $\left(\mathrm{C}_{6} \mathrm{D}_{6}, 400 \mathrm{MHz}\right): \delta 8.30(\mathrm{~d}, J=8.5 \mathrm{~Hz}, 2 \mathrm{H}), 7.73(\mathrm{~d}, J=8.5 \mathrm{~Hz}, 2 \mathrm{H}), 7.67(\mathrm{~d}, J=8.5 \mathrm{~Hz}, 2 \mathrm{H})$, $7.58(\mathrm{t}, \mathrm{J}=7.5 \mathrm{~Hz}, 2 \mathrm{H}), 7.50-7.30(\mathrm{~m}, 4 \mathrm{H}), 3.75-3.42(\mathrm{~m}, 4 \mathrm{H}), 2.25(\mathrm{~m}, 2 \mathrm{H}), 2.00-1.50(\mathrm{~m}, 24 \mathrm{H})$. ${ }^{13} \mathrm{C}$ NMR $\left(\mathrm{C}_{6} \mathrm{D}_{6}, 100 \mathrm{MHz}\right): \delta 245.7,145.8,136.3,133.9,132.7,128.9,128.7,126.9,126.1$, $125.9,124.4,54.1,41.5,38.0,37.2,36.8,29.3,29.0,28.4,28.3$.

1,3-Bis(2-cyclooctylnaphthalen-1-yl)-imidazolin-2-ylidene (5d). In a glove box, to a suspension of $\mathbf{4 d}(0.400 \mathrm{~g}, 0.63 \mathrm{mmol})$ in THF $(50 \mathrm{ml}), \mathrm{NaH}$ (55 to $65 \%$ suspension in mineral oil, $0.029 \mathrm{~g}, 0.76 \mathrm{mmol}$ ) and a catalytic amount of $\mathrm{KO}^{t} \mathrm{Bu}$ were added. The obtained mixture was heated to reflux with a heat gun for a few minutes to initiate the reaction and then reaction was stirred at room temperature for $3 \mathrm{~h}$. It was then slowly filtered through celite to eliminate the inorganic salts. After evaporation of the solvent, $5 \mathrm{ml} \mathrm{of} \mathrm{Et}_{2} \mathrm{O}$ were added to the sticky pink solid 
and the resulting suspension was stirred for 5 minutes. The solvent was decanted and the pink solid was dried in high vacuum ( $0.310 \mathrm{~g}, 90 \%$ yield). From NMR analysis $17 \%$ of the syn isomer was detected. (Due to overlap of most of the signals for both isomers, only the ones related to the major isomer are reported). ${ }^{1} \mathrm{H}$ NMR $\left(\mathrm{C}_{6} \mathrm{D}_{6}, 400 \mathrm{MHz}\right): \delta 8.32(\mathrm{~d}, J=8.2 \mathrm{~Hz}, 2 \mathrm{H}), 7.74(\mathrm{~d}, J=$ $8.3 \mathrm{~Hz}, 2 \mathrm{H}), 7.68$ (d, $J=8.4 \mathrm{~Hz}, 2 \mathrm{H}), 7.59$ (m, 2H), 7.37 (m, 2H), 3.80-3.40 (m, 6H), 2.22-1.4 $(\mathrm{m}, 28 \mathrm{H}) .{ }^{13} \mathrm{C}$ NMR $\left(\mathrm{C}_{6} \mathrm{D}_{6}, 100 \mathrm{MHz}\right): \delta 245.8,146.7,136.1,133.9,132.6,128.9,126.9,126.7$, 125.9, 124.6, 54.2, 38.6, 36.4, 36.1, 28.3, 28.1, 27.1, 26.5 .

1,3-Bis(2,7-cyclopentylnaphthalen-1-yl)-imidazolin-2-ylidene (5e). Following the general procedure [4e (0.083 g, $0.11 \mathrm{mmol}), \mathrm{NaH}(0.006 \mathrm{~g}, 0.17 \mathrm{mmol}), \mathrm{KO}^{t} \mathrm{Bu}$ (cat.), THF (20 ml)], the desired compound was obtained as an off-white solid (0.062 g, 92\% yield). From NMR analysis a 1:1 mixture of isomers was observed. ${ }^{1} \mathrm{H}$ NMR $\left(\mathrm{C}_{6} \mathrm{D}_{6}, 500 \mathrm{MHz}\right): \delta 8.20(\mathrm{~s}, 1 \mathrm{H}), 8.11(\mathrm{~s}, 8.10)$, $7.74(\mathrm{~m}, 4 \mathrm{H}), 7.38(\mathrm{~m}, 4 \mathrm{H}), 3.97-3.18(\mathrm{~m}, 8 \mathrm{H}), 2.40-1.60(\mathrm{~m}, 32 \mathrm{H}) .{ }^{13} \mathrm{C}$ NMR $\left(\mathrm{C}_{6} \mathrm{D}_{6}, 125 \mathrm{MHz}\right)$ : $\delta 246.1,245.7,145.0,144.9,142.4,142.2,138.0,137.9,132.8,132.7,132.6,129.1,129.0,128.7$, $125.9,125.7,124.9,122.0,121.5,54.0,53.9,47.6,47.5,41.3,36.2,36.1,35.9,35.8,35.6,35.5$, $35.3,35.2,27.4,27.3,27.0,26.5,26.4,26.3$.

1,3-Bis(2,7-cyclohexylnaphthalen-1-yl)-imidazolin-2-ylidene (5f). Following the general procedure [4f (0.408 g, $0.54 \mathrm{mmol}), \mathrm{NaH}(0.025 \mathrm{~g}, 0.65 \mathrm{mmol}), \mathrm{KO}^{t} \mathrm{Bu}$ (cat.), THF (50 ml)], the desired compound was obtained as a pink solid (0.351 g, 99\% yield). From NMR analysis only trace amounts of the syn isomer can be detected (less then 5\%). ${ }^{1} \mathrm{H} \mathrm{NMR}\left(\mathrm{C}_{6} \mathrm{D}_{6}, 400 \mathrm{MHz}\right): \delta$ $8.22(\mathrm{~s}, 2 \mathrm{H}), 7.82(\mathrm{~d}, J=8.4 \mathrm{~Hz}, 2 \mathrm{H}), 7.74(\mathrm{~d}, J=8.5 \mathrm{~Hz} 2 \mathrm{H}), 7.47(\mathrm{~d}, J=8.5 \mathrm{~Hz} 2 \mathrm{H}), 7.42(\mathrm{~m}$, $2 \mathrm{H}), 3.9-3.35(\mathrm{~m}, 6 \mathrm{H}), 2.96(\mathrm{~m}, 2 \mathrm{H}), 2.38-1.30(\mathrm{~m}, 40 \mathrm{H}) .{ }^{13} \mathrm{C} \mathrm{NMR}\left(\mathrm{C}_{6} \mathrm{D}_{6}, 100 \mathrm{MHz}\right): \delta 245.7$, $146.7,143.9,137.2,132.9,132.8,129.2,128.1,125.3,125.1,121.6,68.2,54.1,46.8,40.5,35.7$, $35.2,35.1,34.9,28.4,27.8,27.7,27.6,27.2,26.9,26.2$.

1,3-Bis(2,7-cycloheptylnaphthalen-1-yl)-imidazolin-2-ylidene (5g). Following the general procedure $\left[4 \mathrm{~g}(0.103 \mathrm{~g}, 0.12 \mathrm{mmol}), \mathrm{NaH}(0.006 \mathrm{~g}, 0.15 \mathrm{mmol}), \mathrm{KO}^{t} \mathrm{Bu}\right.$ (cat.), THF (30 ml)], the desired product was obtained as a yellow-orange solid $(0.090 \mathrm{~g}, 91 \%$ yield $)$. From NMR analysis, $5 \%$ of the syn isomer can be detected. ${ }^{1} \mathrm{H}$ NMR $\left(\mathrm{C}_{6} \mathrm{D}_{6}, 500 \mathrm{MHz}\right): \delta 8.13(\mathrm{~s}, 2 \mathrm{H}), 7.76$ $(\mathrm{d}, J=8.4 \mathrm{~Hz}, 2 \mathrm{H}), 7.68(\mathrm{~d}, J=8.5 \mathrm{~Hz}, 2 \mathrm{H}), 7.38(\mathrm{~m}, 4 \mathrm{H}), 3.80(\mathrm{~m}, 2 \mathrm{H}), 3.52(\mathrm{~m}, 2 \mathrm{H}), 3.40(\mathrm{~m}$, $2 \mathrm{H}), 3.06(\mathrm{~m}, 2 \mathrm{H}), 2.42-1.3(\mathrm{~m}, 48 \mathrm{H}) .{ }^{13} \mathrm{C} \mathrm{NMR}\left(\mathrm{C}_{6} \mathrm{D}_{6}, 125 \mathrm{MHz}\right): \delta 246.2,148.6,145.8,136.1$, $132.6,132.5,129.5,128.7,125.5,125.1,121.0,54.2,49.2,42.4,38.2,37.7,37.6,37.3,29.3$, $29.0,28.7,28.6,28.4,28.1,28.0,27.8$.

1,3-Bis(2,7-cyclooctylnaphthalen-1-yl)-imidazolin-2-ylidene $(5 \mathrm{~h})$. Following the general procedure [4b (0.104 g, $0.12 \mathrm{mmol})$, NaH (0.006 g, $0.14 \mathrm{mmol}), \mathrm{KO}^{t} \mathrm{Bu}$ (cat.), THF (30 ml)], the desired product was obtained as a white solid ( $0.067 \mathrm{~g}, 70 \%$ yield). From NMR analysis 5\% of the syn isomer can be detected. ${ }^{1} \mathrm{H}$ NMR $\left(\mathrm{C}_{6} \mathrm{D}_{6}, 400 \mathrm{MHz}\right): \delta 8.23(\mathrm{~s}, 2 \mathrm{H}), 7.89(\mathrm{~d}, J=8.4 \mathrm{~Hz}$, $2 \mathrm{H}), 7.80(\mathrm{~d}, J=8.6 \mathrm{~Hz}, 2 \mathrm{H}), 7.55(\mathrm{~d}, J=8.6 \mathrm{~Hz}, 2 \mathrm{H}), 7.50$ (dd, $J=8.4,1.2 \mathrm{~Hz}, 2 \mathrm{H}), 3.97$ (br, 2H), 3.77 (br, 2H), 3.57 (br, 2H), 3.27 (br, 2H), 2.40-1.73 (m, 56H). ${ }^{13} \mathrm{C} \mathrm{NMR}\left(\mathrm{C}_{6} \mathrm{D}_{6}, 100 \mathrm{MHz}\right)$ : $\delta 246.6,149.1,146.1,136.2,132.6,132.5,129.4,128.2,126.0,125.5,121.1,54.1,47.2,40.7$, $36.2,35.4,34.3,28.7,27.9,27.7,27.6,27.0,26.9,26.7,26.6,26.2,25.9$. 


\section{Acknowledgements}

We thank the Alfred Werner Foundation (R.D.), the Swiss National Foundation (L.W.), the Roche Research Foundation (E.D.), and the University of Zurich (M.G., E.D.) for support.

\section{References and Notes}

1. For books on N-heterocyclic carbenes, see: (a) N-Heterocyclic Carbene in Synthesis; Nolan S. P., Ed.; Wiley-VCH: Weinheim, Germany, 2006. (b) N-Heterocyclic Carbenes in Transition Metal Catalysis; Glorius, F., Ed.; Topics in Organometallic Chemistry; Springer: Berlin, Germany, 2007; Vol 21.

2. For reviews, see: (a) Herrmann, W. A. Angew. Chem. Int. Ed. 2002, 41, 1290. (b) Kantchev, E. A. B.; O'Brien, C. J.; Organ, M. G. Angew. Chem. Int. Ed. 2007, 46, 2768. (c) DiezGonzalez, S.; Marion, N.; Nolan, S. P. Chem. Rev. 2009, 109, 3612. (d) Poyatos, M.; Mata, J. A.; Peris, E. Chem. Rev. 2009, 109, 3677. (e) Somojlowicz, C.; Bieniek, M.; Grela, K. Chem. Rev. 2009, 109, 3608. (f) van Otterlo, W. A. L.; de Koning, C. B. Chem. Rev. 2009, 109, 3743. (g) Monfette, S.; Fogg, D. E. Chem. Rev. 2009, 109, 3783. (h) Alcaaide, B.; Almendros, P.; Luna, A. Chem. Rev. 2009, 109, 3817. (i) Vougioukalakis, G. C.; Grubbs, R. H. Chem. Rev. 2009, 109, 1746.

3. Arduengo, A. J.; Harlow, R. L.; Kline, M. J. Am. Chem. Soc. 1991, 113, 361.

4. Arduengo, A. J.; Goerlich, J. R.; Marshall, W. J. J. Am. Chem. Soc. 1995, 117, 11027.

5. Kuhn, N.; Kratz, T. Synthesis 1993, 561.

6. Dimerization can only be achieved by forcing the system to adopt a dimeric structure, see: Taton, T. A.; Chen, P. Angew. Chem. Int. Ed. Engl. 1996, 35, 1011.

7. Poater, A.; Ragone, F.; Giudice, S.; Costabile, C.; Dorta, R.; Nolan, S. P.; Cavallo, L. Organometallics 2008, 27, 2679, and references therein.

8. For known, stable examples of saturated 5-membered NHCs, see reference 4 and: (a) Denk, M. K.; Tadani, A.; Hatano, K.; Lough, A. Angew. Chem. Int. Ed. Engl. 1997, 36, 2607. (b) Arduengo, A. J.; Krafczyk, R.; Schmutzler, R.; Craig, H. A.; Hugh, A.; Goerlich, J. R.; Marshall, W. J.; Unverzagt, M. Tetrahedron 1999, 55, 14523. (c) Denk, M. K.; Hezarkhani, A.; Zheng, F.-L. Eur. J. Inorg. Chem. 2007, 3527.

9. Saturated N-heterocyclic carbenes with limited stability can sometimes be generated in situ and bound to a metal before dimerization occurs, see for example: (a) Berlin, J. M.; Campbell, K.; Ritter, T.; Funk, T. W.; Chlenov, A.; Grubbs, R. H. Org. Lett. 2007, 9, 1339. (b) Stewart, I. C.; Ung, T.; Pletnev, A. A.; Berlin, J. M.; Grubbs, R. H.; Schrodi, Y. Org. Lett. 2007, 9, 1589. (c) Chung, C. K.; Grubbs, R. H. Org. Lett. 2008, 10, 2693.

10. (a) Luan, X.; Mariz, R.; Gatti, M.; Costabile, C.; Poater, A.; Cavallo, L.; Linden, A.; Dorta, R. J. Am. Chem. Soc. 2008, 130, 6848. (b) Vieille-Petit, L.; Luan, X.; Mariz, R.; Blumentritt, S.; Linden, A.; Dorta, R. Eur. J. Inorg. Chem. 2009, 1861. 
11. See reference 10. (b) Similar NHCs with unsymmetrical phenyl side chains are fluxional, see: Stewart, I. C.; Benitez, D.; O’Leary, D. J.; Tkatchouk, E.; Day, M. W.; Goddard, W. A.; Grubbs, R. H. J. Am. Chem. Soc. 2009, 131, 1931.

12. Gatti, M.; Vieille-Petit, L.; Luan, X.; Mariz, R.; Drinkel, E.; Linden, A.; Dorta, R. J. Am. Chem. Soc. 2009, 131, 9498.

13. Cahiez, G.; Habiak, V.; Duplais, C.; Moyeux, A. Angew. Chem. Int. Ed. 2007, 46, 4346. For the first efficient coupling of this kind, see: (b) Nakamura, M.; Matsuo, K.; Ito, S.; Nakamura, E. J. Am. Chem. Soc. 2004, 126, 3686.

14. This reagent is commercially available but expensive. It can be synthesized in multigramscale by adapting the following procedure (see experimental part for details): Neenan, X. T.; Whitesides, G. M. J. Org. Chem. 1988, 53, 2489.

15. The presence of small amounts of iron very often induces the formation of an emulsion that can complicate the workup. Purification through a silicagel plug removes residual metal.

16. (a) Luan, X.; Mariz, R.; Robert, C.; Gatti, M.; Blumentritt, S.; Linden, A.; Dorta, R. Org. Lett. 2008, 10, 5569. (b) Luan, X.; Wu, L.; Drinkel, E.; Mariz, R.; Gatti, M.; Dorta, R. Org. Lett. 2010, 12, 1912.

17. Regioselectivity is already quite good at $0^{\circ} \mathrm{C}$ and ca. $80 \%$ of the right isomer is obtained. Our previously reported synthesis indeed employed this procedure, which should therefore be adapted following the synthetic details given in the experimental part of this paper.

18. Seiders, T. J.; Ward, D. W., Grubbs, R. H. Org. Lett. 2001, 3, 3225.

19. In the experimental section, signals of the carbenic carbon of the syn isomer are reported only when present in sufficient amount.

20. CCDC-790841-790844 contain the supplementary crystallographic data for $\mathbf{4 c ,} \mathbf{4 f}, \mathbf{4 g}$ and 5b reported in this paper. These data can be obtained free of charge from The Cambridge Crystallographic Data Centre via www.ccdc.cam.ac.uk/data_request/cif.

21. Final purification through crystallization from ethanol as reported in ref. 14 should be avoided. The compound crystallizes with 1 equivalent of solvent impeeding proper generation of the di-Grignard reagent in the subsequent step.

22. Because of the heavy precipitate, the cannula diameter has to be sufficient for effective operation. Alternatively, a dropping funnel can be used for the addition.

23. In $\mathrm{CDCl}_{3}$, the ${ }^{1} \mathrm{H}-\mathrm{NMR}$ spectra of this molecule is particularly complicated. We suppose that this is due to strong aggregation phenomena. In DMSO- $\mathrm{d}_{6}$ the solubility is very low. 